3

4

5

6

7

8

9

10

11

12

13

14

15

16

17

18

19

20

21

22

23

24

25

26

27

28

29

30

31

32

33

\title{
Spotting genome-wide pigmentation variation in a brown trout admixture context
}

T. VALETTE ${ }^{1 *}$, M. LeitWein ${ }^{1,4^{*}}$, J.-M. LASCAUX ${ }^{2}$, E. DeSMARAIS ${ }^{1}$, P. BERREBI ${ }^{1,3}$ \& B. GUINAND ${ }^{1 \#}$

${ }^{1}$ : UMR ISEM - CNRS IRD UM EPHE - Montpellier, France

2 : ECOGEA - Muret, France

${ }^{3}$ : GENOME - Recherche et Diagnostic - Saint Just, France

${ }^{4}$ : present address : Institut de Biologie Intégrative et des Systèmes (IBIS), Université Laval Québec, Canada

(8)

18

$$
* \text { : contributed equally }
$$

\# : correspondence: bruno.guinand@umontpellier.fr

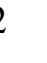

3
ORCID IDs:
B. GUINAND
$0000-0002-6934-1677$
M. LEITWEIN
0000-0001-5172-0970
P. BERREBI
0000-0002-9026-4987

$\underline{\text { Running title }}$ : Admixture and pigmentation in brown trout 


\section{ABSTRACT}

35 Variation in body pigmentation attracted fish biologists for a while, but high-throughput 36 genomic studies investigating its molecular basis remain limited to few species and associated 37 conservation issues ignored. Using 75,684 SNPs, we explored the genomic basis of

38 pigmentation pattern variation among individuals of the Atlantic and Mediterranean clades of 39 the brown trout (Salmo trutta), a polytypic species in which Atlantic hatchery individuals are 40 commonly used to supplement local wild populations. Using redundancy analyses and 41 genome-wide association studies, a set of 337 independent "colour patterning loci" (CPLs) 42 significantly associated with pigmentation traits such as the number of red and black spots on 43 flanks, or the presence of a black spot on the pre-opercular bone was identified. CPLs map 44 onto 35 out of 40 brown trout linkage groups indicating a polygenic basis to pigmentation 45 patterns. They are mostly located in coding regions (43.4\%) of 223 candidate genes, and 46 correspond to GO-terms known to be involved in pigmentation (e.g. calcium and ion-binding, 47 cell adhesion). Annotated candidates include genes with known pigmentation effects (e.g. 48 SOX10, PEML, SLC45A2), but also the Gap-junction $\Delta 2$ (GJD2) gene already shown 49 differentially expressed in trout skin. Patterns of admixture were found significantly distinct 50 when using either the full SNP data set or the set of CPLs, indicating that pigmentation 51 patterns accessible to practitioners are not a reliable proxy of genome-wide admixture. 52 Consequences for management are discussed.

54 Keywords: ddRAD sequencing, admixture mapping, multi-trait phenotype, local ancestry, 55 drift, salmonid, management 


\section{INTRODUCTION}

The study of pigmentation has a peculiar place in modern biology as colour and its patterning play important roles in natural, artificial and sexual selection (Cieslak, Reissmann, Hofreiter, \& Ludwig, 2011; Cuthill et al., 2017). The biology and evolution of animal colouration

61 largely benefited over the past few years in the development of high-throughput sequencing techniques (San José \& Roulin, 2017; Orteu \& Jiggins, 2020). While supergenes and large effect mutations have been shown to support pigmentation patterns in many organisms (Orteu \& Jiggins, 2020), genomic studies also generated a huge literature that underscored their polygenic basis (e.g. skin and hair colour in human: Crawford et al., 2017; Pavan \& Sturm, 2019; structural colour variation or eyespot numbers in butterflies: Brien et al., 2019; RiveraColón, Westermann, van Belleghem, Monteiro, \& Papa, 2020). Recent research showed that pigmentation variation may result from effects propagated during development by loci belonging to regulatory networks to hub or master genes often sufficient to explain most of

70 the causal variation with colour expression and/or patterning (e.g. Arnould et al., 2013;

71 Ordway, Hancuch, Johnson, Wiliams, \& Rebeiz, 2014; Ding et al., 2020, Orteu \& Jiggins, 2020).

If early genetic and molecular studies were interested in colour and pigmentation patterns in fish - e.g. sex-linked colour variation (Kottler \& Schartl, 2018) - the issue of body pigmentation gained interest with the establishment of zebrafish and medaka as model species (Parichy, 2006; Takeda \& Shimada, 2010; Singh \& Nüsslein-Völlard, 2015; Nüsslein-Völlard

$77 \&$ Singh, 2017) and from comparisons with higher vertebrates (e.g. Kelsh, Harris, Colanesi, \& 78 Erickson, 2009). Pigment cells (i.e. chromatophores; mainly melanophores, iridophores, leucophores and xanthophores) are distributed in the hypo- and the epidermis in fish, and mutational or other analyses allowed for increased understanding in the mechanisms of 
81 pigment cell fates during development and their resulting distribution (Kelsh et al., 2004,

82 2009; Kimura et al., 2014; Eom, Bain, Patterson, Grout, \& Parichy, 2015; Nüsslein-Völlard \&

83 Singh, 2017; Parichy \& Spiewak, 2015; Singh \& Nüsslein-Völlard, 2015; Salis et al., 2018;

84 Volkening 2020). Studies now extend to other fish species (Maan \& Sfec, 2013; Irion \&

85 Nüsslein-Völlard, 2019) and to a large array of eco-evolutionary questions regarding the

86 involvement of genes or regulatory pathways in fish pigmentation, its epistatic and pleiotropic

87 nature, its modularity and its control, its role in speciation as well as the impact of whole-

88 genome duplication that promoted the diversification of pigment cell lineages (Hultman,

89 Bahary, Zon, \& Johnson, 2007; Miller et al., 2007; Braasch, Brunet, Volff, \& Schartl, 2009;

90 Roberts, Ser \& Kocher, 2009; Albertson et al., 2014; Santos et al. 2014; Ceinos, Guillot,

91 Kelsh, Cerdá-Reveter, \& Rotlland, 2015; Yong, Peichel, \& McKinnon, 2015; Kimura,

92 Takehana, \& Naruse, 2017; Roberts, Moore, \& Kocher, 2017; Lorin, Brunet, Laudet, \& Volff,

93 2018; Kratochwil et al., 2018; Nagao et al., 2018; Cal et al., 2019; Lewis et al., 2019; Liang,

94 Gerwin, Meyer, \& Kratochwil, 2020). Studies also engaged fish research in high-throughput

95 genomic approaches of pigmentation variation (Tripathi et al., 2009; Greenwood et al., 2011;

96 Malek, Boughman, Dworkin, \& Peichel, 2012; O’Quin, Drilea, Conte, \& Kocher, 2013;

97 Henning, Jones, Franchini, \& Meyer, 2013; Albertson et al., 2014; Henning, Lee, Franchini,

98 \& Meyer, 2014; Xu et al., 2014; Bian et al., 2016; Zhu et al., 2016; Roberts et al. 2017; Kon

99 et al., 2020). However, in spite of this impressive research, the genomics of pigmentation

100 variation remain poorly investigated in fish compared to other phenotypic traits (Peichel \&

101 Marques, 2017). Furthermore, links between pigmentation and conservation genomic issues

102 remain absent (but see Boulding et al., 2008) while this topic emerges in, e.g., birds, notably

103 regarding the impacts of admixture (Toews et al., 2016; Hanna, Dumbacher, Bowie,

104 Henderson, \& Wall, 2018; Billerman, Cicero, Bowie, \& Carling, 2019). 
Salmonids represent a large fish family with a diverse and complex body pigmentation

106 going from continuous colour to spotty, marbled, blotchy and striped patterns. If whole body

107 colouration or specific coloured elements have a genetic basis (e.g. Blanc, Poisson, \& Vibert,

108 1982; Skaala \& Jørstad, 1988; Blanc, Chevassus, \& Krieg, 1994; Blanc, Poisson, \& Quillet,

109 2006; Boulding et al., 2008; Colihueque, 2010; Nilsson et al., 2016), another part is plastic

110 (Colihueque, 2010; Westley, Stanley, \& Fleming, 2013; Jørgensen et al., 2018). Colour

111 patterns support differences in coping styles (Kittilsen et al., 2009; Brännäs et al., 2016) or in

112 the physiological adjustments necessary to avoid predation and match with environmental

113 variability (e.g. Miyamoto, 2016; Jacquin et al., 2017; Zastavniouk, Weir, \& Fraser, 2017). In

114 salmonids, pigmentation and colour are also known to interact with social hierarchies,

115 influence mate choice and affect fitness (e.g. O’Connor, Metcalfe, \& Taylor, 2000; Wedekind,

116 Jacob, Evanno, Nusslé, \& Müller, 2008; Marie-Orléach et al., 2014; Watt, Swanson, Miller,

117 Chen, \& May, 2017, Auld, Noakes, \& Banks, 2019). However, the genomic basis of their

118 pigmentation patterns remains largely unexplored, with limited insights coming from

119 quantitative trait loci (QTL) (Boulding et al., 2008) or few gene expression studies (Sivka,

120 Snoj, Palandačić, \& Sušnik Bajec, 2013; Djurdjevič, Furmanek, Miyazawa, \& Sušnik Bajec,

121 2019). Furthermore, as pigmentation patterns may reflect admixture in salmonids (Largiadèr

122 \& Scholl, 1996; Mezzera, Largiadèr, \& Scholl, 1997; Aparicio, García-Berthou, Araguas,

123 Martinez, \& Garcia-Marin, 2005; Miyazawa, Okamoto, \& Kondo, 2010; Kirczuk \&

124 Domagała; 2012, Kocabaş, Kutluyer, \& Başçinar, 2018), it appears necessary to improve

125 knowledge on the genotype-phenotype association supporting observed pigmentation patterns.

126 Indeed, these patterns may inform on individual origin and use to improve management

127 knowledge, decisions or policies (Largiadèr \& Scholl, 1996; Poteaux \& Berrebi, 1997;

128 Delling, Crivelli, Rubin, \& Berrebi, 2000; Aparicio et al., 2005; Kocabaș et al., 2011; Marin,

129 Coon, \& Fraser, 2017; Duchi, 2018; Lorenzoni et al., 2019). It is thus important to evaluate if 
130 loci supporting phenotypic divergence for pigmentation patterning reflect genome-wide

131 admixture.

132 In this study, we take advantage of former genomic knowledge established in the

133 brown trout (Leitwein, Gagnaire, Desmarais, Berrebi, \& Guinand, 2018) to search for the loci

134 responsible for body pigmentation variation among populations of two clades recognised in

135 this species (Atlantic and Mediterranean; Bernatchez, 2001; Sanz, 2018). Then, we investigate

136 if those loci could be a relevant proxy to monitor hybridization and genome-wide admixture

137 among individuals of these clades.

\section{MATERIALS AND METHODS}

\section{1 - BROWN TROUT'S GENOMICS DATA}

143 Double digested restriction site-associated DNA sequencing (ddRADseq) data used in this

144 study are from Leitwein et al. (2018). The data set consists in 75,684 genome-wide SNPs

145 (40,519 RAD-loci or haplotypes) for 112 trout of hatchery and wild caught origins. Eighty-

146 two wild caught individuals were fished in the headwaters of three rivers within the

147 Mediterranean Orb River catchment (France) (Gravezon, Mare and Upper Orb rivers;

148 Leitwein et al., 2018). This catchment has been seeded by hatchery fish of both Atlantic and

149 Mediterranean origins for decades. This stopped in 2004, but unintentional releases due to

150 flooding of private hatcheries are documented (Leitwein et al., 2018). Analyses showed that

151 these wild caught individuals consisted in hatchery individuals of both Mediterranean and

152 Atlantic origins, F1's, F2's, backcrossed individuals, and 'pure' natural Mediterranean fish

153 (Leitwein et al., 2018). 'Early' and 'late' backcrossed individuals correspond to 
154 Mediterranean wild-caught fish that contained distinct distributions of Atlantic ancestry tracts

155 in their genome. Thirty individuals of the domestic Atlantic $(N=15)$ and Mediterranean $(N=$

156 15) strains were also included in the analysis. Mediterranean hatchery fish have been

157 randomly sampled in a local strain formerly established using mature trout from the Gravezon

158 River by the Fédération de Pêche de l'Hérault in 2004. Atlantic hatchery fish originated from

159 the Cauterets hatchery that maintains an Atlantic strain distributed worldwide (Bohling,

160 Haffray, \& Berrebi, 2016).

\section{2 - Phenotypic DAta}

163 Acquisition of phenotypic data followed Lascaux (1996) and is used by numerous angler associations and management authorities in France. The set of variables considered in this protocol is listed in Table S1 and illustrated on a picture in Fig. S1. Data were recorded from individual photographs of the 112 fish considered for genomic analyses. Photographs were

167 taken at fishing on slightly anesthetized trout with eugenol. A camera Canon ${ }^{\circledR}$ EOS $1000 \mathrm{D}$ 168 was used. After recovery, fish were released in the wild or in hatchery tanks. Quantitative 169 variables $(N=19)$ and semi-quantitative variables $(N=11)$ were recorded by visual examination of photographs of the left flank of each individual fish. Quantitative variables refer to punctuation patterns of brown trout (e.g. number and diameter of spots) and are recognized important for this species (Blanc et al., 1982, 1994). Semi-quantitative variables

173 refer to 'ornamental' appearance patterns (e.g. parr marks, fringes on fins, white ring around 174 spots) that are important to practitioners or anglers. Each quantitative punctuation variable 175 was measured independently. Ornamental variables have been coded by modalities, either 176 present/absent [1, 2] or, e.g., absent/partial/complete [1, 2, 3] (Tables 1 \& S1). This set of 177 variables avoided focusing only on peculiar attributes of the pigmentation patterns. Other 178 pigmentation traits that can be also important for trout (e.g. background colour, brightness, or 
179 reflectance; Colihueque, 2010) were not considered in this study. Phenotypic data and trout

180 pictures will be deposited on a public repository. Eleven colour patterning variables were

181 found not significantly correlated (Table S2) and retained for subsequent analysis (Table 1).

\section{3 - GENOTYPE-PHENOTYPE ASSOCIATION}

184 The evaluation of the genotype-phenotype association between SNPs and pigmentation/colour

185 traits was performed using three distinct approaches. Hereafter, we coined a 'colour 186 patterning locus' (CPL) any SNP or RAD-locus found significantly associated with a colour

187 variable considered in this study. A CPL is not a 'pigmentation locus' (or gene, if any; see

188 Lorin et al., 2018), but a locus that participate to produce pigmentation and colour 189 information.

190 Redundancy analysis (RDA) - We first used RDA to investigate any association between

191 genomic and colour trait data. RDA is a constrained ordination method in which only the

192 variation of response variables explained by a set of explanatory variables is displayed and 193 analysed (Legendre \& Legendre, 2012). RDA was performed with the remaining 11 194 uncorrelated colour variables as the explanatory and the SNPs as the response variables.

195 Missing genomic data were imputed by the most commonly observed genotype. Missing 196 phenotypic data were imputed by the mean of observed trait for quantitative data, and the 197 most commonly observed phenotype for semi-quantitative data. We classified SNPs as 198 showing statistically significant association with individual pigmentation/ornamental traits 199 when they loaded with more than 2.5 standard deviations (S.D.) from the mean.

200 A forward model selection was used to select for the relevant phenotypic variables 201 structuring the RDA (Blanchet, Legendre, \& Borcard, 2008). In constrained ordination

202 methods like RDA, increasing the number of explanatory variables becomes similar to 
unconstrained ordination method (e.g. principal component analysis) as the percentage of

204 variation explained increases when considering more explanatory variables, while some of 205 them add no relevant information. Models were defined, first including the eleven 206 uncorrelated response variables, then reducing this number. The Aikake Information Criterion

207 was computed in each case to select the most appropriate model (i.e. minimizing deviance).

208 Permutation tests $(N=999)$ were performed by permuting individuals in each model. This

209 procedure was first established for the RDA itself, then for each successive RDA axis to

210 investigate if observed patterns carried significant association between relevant pigmentation

211 traits and SNPs. Analyses were performed with the vegan package (https://cran.r-

212 project.org/web/packages/vegan/index.html). Once relevant colour variables were identified

213 in models, each significant SNP was associated to the pigmentation or ornamental trait it was

214 the most significantly correlated.

215 Genome-wide association studies (GWAS) -A single-trait association was first considered by

216 fitting each colour variable with SNPs by linear regression. We used a penalized maximum-

217 likelihood least absolute shrinkage and selection operator (LASSO) model to select for SNPs 218 implied in each trait association, then solving:

$$
\min _{\left(\beta_{0}, \beta\right) \in \mathbb{R}^{p+1}}\left[\frac{1}{2 N} \sum_{i=1}^{N}\left(y_{i}-\beta_{0}-x_{i} \beta\right)^{2}+\lambda \sum_{j=1}^{p}\left|\beta_{j}\right|\right]
$$

220 in which $Y \in \mathbb{R}$ represents the response colour variable, $X \in \mathbb{R}^{p}$ a vector of predictor variables

221 (i.e. SNPs), $\lambda$ the penalty parameter, $\beta_{0}$ the y-intercept of multiple linear regression, and $\beta \in$

$222 \mathbb{R}^{p}$ a vector of $\beta_{j}$ coefficients (Friedman, Hastie, \& Tibshirani, 2010). This vector of $\beta_{j}$

223 coefficients represents the effect size $\beta_{j}$ of the $j^{\text {th }}$ SNP conditional on the effects of all other

224 SNPs. The penalized term $\lambda$ shrinks the regression coefficient towards zero, keeping only a 
small number of SNPs with large effects in the model. A cyclical coordinate descent

226 procedure was retained for model selection (Friedman et al., 2010). The retained model was

227 determined by cross-validation. $\log (\lambda)$ was estimated by minimizing the mean quadratic error.

228 The number of positive $\beta_{j}$ coefficients was estimated from $\log (\lambda)$, with each $\beta_{j}$ coefficient associated to a suite of SNPs considered as involved in the association. Analyses were performed with the glmnet package (https://cran.r-project.org/package=glmnet). (O'Reilly et al., 2012) to test for the linear combination of phenotypes most associated with the genotypes at each SNP. Such one approach may potentially capture effects hidden to single phenotype GWAS. It performs a 'reversed regression', with multiple phenotype predictors and genetic variant as outcome (i.e. $G$ SNPs $X_{(i)}=\left\{X_{(i 1)}, \ldots, X_{(i G)}\right\}$ are explained by SNP is associated to a multi-trait phenotype (Porter \& O'Reilly, 2017). Permutation tests were performed to determine one adjusted significance threshold to detect false positives

240 (Dudbridge \& Gusnanto, 2008). A probability $P<5 \times 10^{-8}$ was retained to consider one SNP as significantly implied in a multi-trait pigmentation association.

In single- and multi-trait GWAS, we controlled for population stratification by using

243 nine distinct trout samples recognized by the length and number of ancestry tracts (Leitwein

244 et al., 2018). Local ancestry tracts may integrate linkage disequilibrium patterns which are

245 crucial in association studies (e.g. Shriner, 2017; Li, Kemppainen, Rastas, \& Merilä, 2018).

246 The nine groups include the two hatchery samples (Atlantic, Mediterranean), then seven

247 distinct samples of wild-caught trout. Following Leitwein et al. (2018), wild-caught trout were

248 grouped as follows: F1's, F2's, 'early' and 'late' backcrossed individuals, then samples of 249 'pure' wild individuals assigned to each of the three local populations. As some wild caught 
trout were identified as hatchery individuals (Leitwein et al., 2018), they have been grouped

with individuals sampled in the hatchery type they have been previously assigned.

\section{4 - MAPPING AND ANNOTATION}

254 CPLs detected by RDA and GWAS have been mapped on the Atlantic salmon genome 255 (Salmo salar; Lien et al. 2016; Genbank assembly: GCA_000233375.4) and on the high 256 density linkage map of S. trutta (Leitwein et al., 2017). We searched for genes located in a $25725 \mathrm{~kb}$ window upstream or downstream of each colour-associated marker (arbitrary range).

258 When one association with a gene was detected, markers were assigned to coding or non259 coding (intron, upstream or downstream sequences) gene regions, or other specific entities 260 (transposable elements, pseudogenes). Using S. salar annotations as inputs, gene ontologies

261 (GO) for biological processes and molecular functions were derived for genes associated to 262 CPLs using QuickGO (https://www.ebi.ac.uk/QuickGO/). When annotations were unavailable 263 on the salmon genome, a search was launched on UniProtKB

264 (https://www.uniprot.org/uniprot/) for the protein sequence encoded by the gene. Only 265 annotations with similarity $>90 \%$ were retained.

266 Because many genes associated to melanocyte development are also implied in 267 melanoma development when mutated (Patton, Mitchell, \& Naim, 2010; Uong \& Zon, 2010), 268 we further performed a literature search in order to know if genes detected within the $25 \mathrm{~kb}$ 269 windows were previously mentioned in former studies. Queries were made using the gene ID 270 (or aliases taken from GeneCards, https://www.genecards.org/) and a specific keyword. The

271 retained keywords were: skin, melanocyte, melanophore, melanosome, melanoma (squamous, 272 cutaneous and uveal), pigment/-ation, keratinocyte, chromatophore, iridiophore, follicle (hair 273 or skin), nevus/-i, (epi)dermis, vitiligo, erythema/-tous, and sebocyte. This search was updated 
274 until the beginning of June, 2020, each time using the Web of Science, PubMed and Google

275 Scholar.

276

277

\section{5 - GENOMIC DIFFERENTIATION}

278 Distributions of $F_{\mathrm{ST}}$ values were established using all SNPs, then for the subset of CPLs found

279 significant in the RDA and GWAS. Single-locus $F_{\mathrm{ST}}$ values were estimated considering five

280 distinct trout samples: the two samples of hatchery fish, then trout caught in each of the three

281 rivers within the Orb catchment.

282

283

\section{6 - COMPARISON OF INDIVIDUAL ASSIGNMENT}

284 In order to compare if individual assignment (probability of membership) ranked individuals

285 similarly or not using all loci or CPLs only, we first established the probability of 286 membership of individuals to the Atlantic population using independent CPLs defined in this 287 study. Individual admixture proportions were computed with the LEA package (Frichot \& 288 François, 2015), using $K=2$ (Atlantic and Mediterranean clades). We then used the 289 probability of assignment established by Leitwein et al. (2018) that were based on individuals 290 used in this study, using the same set of 40,519 RAD-loci, also considering $K=2$. A

291 Wilcoxon signed-ranked test between each assignment probability distribution was

292 performed. Similar rankings of individuals in assignment will indicate that CPLs represent a 293 proxy of genome-wide admixture, while a significant difference will be indicative of the 294 reverse. 


\section{RESULTS}

\section{1 - REDUNDANCY ANALYSIS}

300 Forward model selection showed that a model based on eight colour variables minimized the 301 deviance in RDA (Macrost, N.PR.Tot, Zeb, Fr.An, L.Lat, Fr.P, Diam.PN, N.PN.Tot) (Table

302 S3). Hereafter, results are reported for this model. Patterns of variation explained by the RDA

303 were found to significantly structure the association between SNPs and pigmentation 304 variables $(P<0.001)$. The first axis of RDA was found to represent $29.81 \%$ of the total inertia

305 (Fig. 1), and was significant either $(P<0.001)$. RDA axis 2 was found to explain only a tiny

306 fraction of observed variation for pigmentation variables (2.10\%; Fig. 1), and be marginally

307 significant $(P=0.051)$. As RDA is a constrained ordination method, constrained inertia (the

308 percentage of variation explained by uncorrelated pigmentation variables) was found to

309 represent $35.50 \%$ of the total inertia. The remaining portion is due to other factors. Axis 1

310 represented approx. 84\% (ratio: 29.81/35.50) of constrained inertia, while axis 2 explained

311 only approx. $6 \%(2.10 / 35.50)$ of inertia.

312 RDA results are represented as a triplot in which individuals are positioned according

313 to the relationship established between response and explanatory variables (Fig. 1). The

314 ornamental trait Macrost (hereby a large pre-opercular black stain/spot) and the pigmentation

315 trait N.PR.Tot (total number of red spots) explained $23.6 \%$ and $22.7 \%$, respectively, of the

316 total loading scores of phenotypic variables onto RDA axis 1. Results showed a clear

317 distinction between colour patterns of Mediterranean and Atlantic hatchery fish (Fig. 1A).

318 Atlantic hatchery fish were characterized by the total number of red spots, while the

319 macrostigma spots, but also zebra marks (Zeb) and total number of black spots (N.PN.Tot)

320 characterized Mediterranean hatchery fish along RDA axis 1. Results confirmed that few wild

321 caught individuals from the Gravezon River were released Atlantic hatchery fish (Leitwein et 
322 al., 2018). Other individuals from the Gravezon River and 'late backcrossed' individuals have

323 patterns more characteristic from hatchery Mediterranean fish (Fig. 1A; the hatchery was

324 seeded by individuals caught in this river [see Materials and Methods section]). Other wild

325 caught individuals are distributed between these extremes, with individuals identified as F1's

326 presenting intermediary positions between wild-caught and wild Mediterranean fish on one

327 side, and Atlantic fish on the other side (Fig. 1A). The position of the wild caught Orb River

328 individuals referred to the marginally significant second axis of the RDA and to specific

329 variables (L. Lat, Fr.P) that were mostly unobserved in other fish (Fig. 1A). F2 individuals

330 presenting these characters were effectively fished in the Upper Orb River, suggesting they

331 possibly inherited colour characters expressed in this local population.

(i.e. > 2.5 S.D. from the mean). Only 22 loci $(0.03 \%)$ were significantly associated to each of

the two axes for distinct phenotypic variables. Different numbers of SNPs were found associated with pigmentation variables: 299 with Fr.P, 269 with N.PR.Tot, 225 with N.PN.Tot, and 213 with Macrost. Macrost showed significance for loci associated to both first and second axis of RDA (yellow circles on Fig.1B). As axis 2 was found marginally significant and substantially affected by individuals from one single population, only SNPs associated to

340 the first RDA axis will be considered further. This discarded loci associated to Fr.P that 341 explained most of the variation for the second RDA axis. Three hundred and twenty SNPs 342 were found associated to the main RDA axis, all of them being associated to Macrost and 343 N.PR.Tot, these variables being negatively correlated (Fig. 1B).

344 As a complement to this analysis and because the threshold of \pm 2.5 S.D. is somewhat 345 arbitrary, we looked back at specific genes known to be involved in colour patterning in 346 vertebrates and fish, and searched for their position within the distribution of loci over the 
347 RDA axis 1 . We detected eight genes representing 30 SNPs for which sequencing reads were

348 available (Fig. S2). One SNP from the Mitf1 (microphthalmia-associated transcription factor

349 1) gene was close to the threshold considered in this study. The Mitfl gene is a master gene

350 for melanocyte differentiation (e.g. Cheli, Ohanna, Ballotti, \& Bertolotto, 2010) and, with a

351 negative value on the first axis of the RDA, this SNP is associated to Macrost, thus the

352 expression of the black colour.

\section{2 - SingLE AND MULTI-TRAIT GWAS}

355 Only two pigmentation variables allowed for relevant LASSO model construction in single

356 trait GWAS after selection of the penalized term using the cyclical descent procedure (Fig.

357 S3): N.PN.Tot (total number of black spots: 17 candidate SNPs) and N.PR.Tot (total number

358 of red spots: 9 candidate SNPs) (Table S4). These two variables were found significant in

359 RDA, and negatively correlated (Fig. 1). Candidate SNPs from single GWAS models are

360 reported in Fig. 2A.

Two multi-trait GWAS models were retained (Fig. 2). As the single-trait GWAS, the

362 first one jointly retained N.PN.Tot and N.PR.Tot as variables for which some SNPs were

363 found associated. The second selected model considered seven of the eight variables formerly

364 retained in the RDA (except Zeb). Seven and thirty-one SNPs were considered as significant

365 in these multi-trait GWAS, respectively (Table S4).

366

Despite some similarities for the pigmentation and colour variables put forward by

367 the different genotype-phenotype associations, only one single SNP (RAD-locus) was found

368 in common between RDA and the single-trait GWAS for number of black spots (Fig. 2A). No

369 other SNP was commonly detected by distinct genotype-phenotype association methods, and

370 especially no SNP shared among GWAS models. It results in a total of 384 SNPs considered 
371 as CPLs putatively implied in pigmentation variation in brown trout $(\sim 0.51 \%$ of the total

372 number of SNPs; 320 coming from RDA and 64 from the single- and multi-trait GWAS

373 models). These CPLs corresponds to 337 independent RAD-loci ( $0.83 \%$ of the total number

374 of RAD-loci).

375

376

\section{3 .3 - GENOMIC DIFFERENTIATION}

377 The distributions of $F_{\text {ST }}$ values for the 40,519 RAD-loci and the 320 CPLs associated to axis 1

378 of the RDA are reported in Fig. 3. The mean $F_{\mathrm{ST}}$ was estimated to $F_{\mathrm{ST}}=0.286$ [95\% CI: 0.284,

3790.287 ] for the full set of SNPs, while this estimate was $F_{\mathrm{ST}}=0.575$ [95\% CI: 0.570-0.583] for

380 the 320 CPLs detected with the RDA. Observed mean $F_{\mathrm{ST}}$ values were $F_{\mathrm{ST}}=0.176$ (min. 0.02

$381-\max : 0.38$ ) and $F_{\mathrm{ST}}=0.025$ (min.: 0.00; max. 0.20) for the single- and the multi-trait GWAS,

382 respectively. Min/max values are reported rather than $95 \%$ CI because the low number of

383 SNPs associated to phenotypic variables in each GWAS. As distributions do not overlap, the

384 mean $F_{\mathrm{ST}}$ value of the $384 \mathrm{CPLs}$ has no real meaning, but is $F_{\mathrm{ST}}=0.547$ [95\% CI: 0.538 -

$3850.555]$.

386

\section{4 - MAPPING ON $S$. TRUTTA LINKAGE GROUPS AND ANNOTATION}

388 We considered only the 337 independent CPLs as linked SNPs provide redundant

389 information. Three hundred independent CPLs were mapped onto 35 of the forty brown trout

390 LGs defined in Leitwein et al. (2017) (Fig. 4), while 37 of them could not be adequately

391 positioned on the high density linkage map of Leitwein et al. (2017). Their position relative to

392 other RAD-loci suffered ambiguity. The distribution of these 300 CPLs on each LG varied

393 from zero (LG13, LG14, LG15, LG20, LG39) to 86 (LG31). The 337 CPLs have been

394 mapped on the Atlantic salmon genome and their annotations are given in Table S4. Among 
395 the 337 independent CPLs, $\sim 75.9 \%$ were found located in coding (43.4\%) or so-called

396 "regulatory regions" (32.5\%; $17.8 \%$ upstream and $14.7 \%$ downstream genes) within the $25 \mathrm{~kb}$

397 window retained around genes. This represents 245 loci associated to one gene (223 distinct

398 genes; Table S4). Approximately $22.0 \%$ of the CPLs did not match any gene in the $25 \mathrm{~kb}$

399 window, and $2 \%$ were found associated to pseudogenes or long non-coding (lnc) RNA (Fig.

400 S4). LncRNAs might be important in fish colour patterning (Luo et al., 2019), but not

401 considered further. Overall $89.86 \%$ (200 out of 223) of the genes in close vicinity of the CPLs

402 detected in this study have been mentioned in the literature dealing with colour, or affecting 403 integument patterning, differentiation or structure. Table S4 provides details on gene names,

404 their position and the location of associated CPL; references mentioning each of these 200

405 CPLs are reported.

406 An excerpt of twenty-four of these 200 genes (12.0\%) is reported in Table 2 to 407 summarize data. Among these genes, nine candidate genes were detected using GWAS (four 408 by single-, and five by multi-trait GWAS) (Table 2). The RAD-locus detected by both RDA 409 and single-trait GWAS for black spotting is located $21 \mathrm{~kb}$ downstream of GJD2 (Gap410 junction protein $\Delta 2$ gene; located on LG9 of $S$. trutta; Table S4). This gene was formerly 411 found differentially expressed in trout skin (Djurdjevič et al., 2019).

\section{5 - GO TERMS}

414 GO terms for molecular functions and biological processes of the 337 CPLs are reported in

415 Fig. S5. Calcium and metal ion binding were found to be the most representative molecular 416 functions. GO-terms for biological functions highlighted cellular adhesion processes (Fig. 417 S5A), signal transduction and translation, and transmembrane transport (Fig. S5B). 


\section{6 - WILCOXON SIGNED-RANKED TEST ON INDIVIDUAL ASSIGNMENT}

420 As expected because of large differences in mean $F_{\mathrm{ST}}$ values, individual rankings in

421 probability of membership were found to significantly differ when using the whole RAD-loci

422 established in Leitwein et al. (2018) and the independent CPL data sets defined in this study

423 (Wilcoxon signed-rank test, $P<10^{-5}$ ). As CPLs were mainly associated to red and black spots

424 (N.PN.Tot, N.PR.Tot, Macrost) in the GWAS and the RDA, this suggests that such patterns

425 are not reliable indicators of genome-wide admixture, while frequently, but intuitively used

426 by managers.

\section{DISCUSSION}

431 Because of the importance of visual information in natural and sexual selection, we aimed to 432 investigate the genomic basis of body colour patterning between trout from the Mediterranean and Atlantic clades recognized in this species. The second one is heavily used for stocking

434 practices and has been introduced worldwide, including Mediterranean watersheds (Elliott, 435 1989; Budy et al., 2013). Based on findings by Leitwein et al. (2018), admixture (ancestry) 436 patterns were included in our study and improved the detection of significant associations as 437 shown in previous studies (e.g. Shriver et al., 2003; Daya et al., 2014; Pallares, Harr, Turner, 438 \& Tautz, 2014; Brelsford, Toews, \& Irwin, 2017), including fish (Malek et al., 2012). This 439 information allowed for the detection of CPLs associated to candidate genes formerly 440 identified in pigmentation studies. These CPLs complement genome-wide gene expression 441 studies by Djurdjevič et al (2019) and improve knowledge on the genomic basis of 442 pigmentation in the brown trout. While pigmentation patterns are important to evaluate the 
443 impact of hatchery individuals into wild trout populations (Mezzera et al., 1997; Aparicio et

444 al., 2005), it is premature to rely on phenotypic colour patterns as a proxy of genome-wide 445 admixture to promote management decisions.

\section{1 - ASSOCIATIONS PROMOTE SPOTTING TRAITS...}

448 Genotype-phenotype associations used in this study principally put forward the numbers of 449 red and black spots and the presence/absence of the black pre-opercular spot as the main 450 pigmentation variables that aimed to distinguish Mediterranean and Atlantic trout. This was 451 expected as these variables have been repeatedly shown to characterize pigmentation

452 differences between Atlantic or Mediterranean trout in studies previously conducted in France 453 (Poteaux \& Berrebi, 1997) and Spain (Aparicio et al., 2005). These traits were not always 454 found in Italian populations, and others may prevail locally (e.g. patterns of the adipose fin) 455 (see Lorenzoni et al., 2019). While focusing on few local French populations, results 456 presented in this study thus reflect most of the former results obtained for these two clades at 457 a broader scale. Nevertheless, as for Italian populations, model selection showed that 458 potentially more variables might be considered at the local scale. Spotting traits do not 459 uncover the full panel of pigmentation variation present in a polytypic species like brown 460 trout. Further works participating to establish the genotype-phenotype association for colour 461 pattern in brown trout should integrate other tools and variables than used in this study. 462 Recent software developments may participate to improve this issue (Endler, Cole, \& Kranz, 463 2018; Van Bellenghem et al., 2018; Chan, Stevens, \& Todd, 2019), including additional data 464 on hue, reflectance or brightness. 
467 If the different genotype-phenotype association methods used in our study retrieved the same

468 pigmentation variables, CPLs detected by RDA and GWAS appeared clearly distinct with 469 exception of GJD2 formerly studied in trout (Djurdjevič et al., 2019). Indeed, the identity of

470 loci considered associated to a single and/or multi-trait phenotype, their number, and their

471 respective levels of genomic differentiation did not overlap. This is expected as models

472 behind methods are different and may direct the analyses towards specific findings. For

473 example, we already mentioned that the shrinkage procedure in LASSO aimed to keep only

474 SNPs with large effects while discarding others, also explaining why far less CPLs come from

475 GWAS. It is also widely known that results from single-trait GWAS lack power when few 476 individuals or SNPs are considered (e.g. Schielzeth \& Husby, 2014), especially when

477 considering wild populations (Kardos, Husby, McFarlane, Qvanström, \& Ellegren, 2018;

478 Santure \& Garant, 2018) and polygenic variation (Berg \& Coop, 2014). These drawbacks

479 were moderated by consideration of population stratification based on ancestry patterns. In the

480 opposite, GWAS retrieved loci with low and sometimes null $F_{S T}$ values that RDA ignored 481 while balancing selection is crucial to explain pigmentation variation (e.g. Croucher, Oxford, 482 Lam, \& Gillespie, 2011; Lindtke et al., 2017; Schweizer et al., 2018). We do not expand 483 further. A sub-section below is devoted to RDA that, despite caveats, remains potentially 484 neglected in association studies.

We prefer to adopt a pragmatic view: RDA and GWAS detected a large proportion 486 of markers formerly mentioned in the literature on skin and pigmentation. Over the 337 487 independent CPLs retained overall, 245 loci mapped within a $25 \mathrm{~kb}$ window downstream or 488 upstream 223 distinct genes. Two hundreds of them were formerly mentioned in our literature 489 survey regarding issues and processes dealing with colour patterning or skin-related issues. 490 The GO terms highlighted by our study for both molecular functions and biological processes 491 are crucial to pigmentation patterning. Calcium binding is known to be important for 
492 melanogenesis (Bush \& Simon, 2007; Bellono \& Oancea, 2014; Jia et al., 2020). For

493 example, the $S L C 45 A 2$ gene detected in this study that encodes for a transporter protein

494 involved in the production and regulation of melanin is regulated by calcium binding levels

495 (Ginger et al., 2008; Bellono \& Oancea, 2014). Melanin is also known to deeply interact with

496 metal ions at various steps of melanogenesis (Hong \& Simon, 2007). Metal ion binding is

497 necessary in the integrin-mediated signaling pathways whose importance in colour patterning

498 is well-known (Kelsh et al., 2009; Klotz et al., 2018). Zinc binding is critical to control

499 melanocyte migration to the epidermis (Denecker et al., 2014) and microtubule activity for

500 melanosome trafficking within melanocytes (Aspengren, Hedberg, Sköld, \& Wallin, 2009).

501 Other functions such ATP- or DNA- binding activities participate to melanosome/melanocyte

502 biology and regulation (Levy et al., 2006; Heimerl, Bosserhof, Langmann, Ecker, \& Schmitz,

503 2007). DNA-binding especially concerns transcription factors that promote growth, survival

504 and differentiation of melanocytes. The main biological functions highlighted in this study

505 (cellular adhesion processes, signal transduction and translation, transmembrane transport) are

506 involved in chromatophore or melanocyte development, interactions among chromatophores

507 or between melanocytes and other cell types (fibroblasts, keratinocytes) (Yamaguchi,

508 Brenner, \& Hearing, 2007; Raposo \& Marks, 2007; Kelsh et al., 2009; Mahalwar, Singh,

509 Fadeev, Nüsslein-Vollard, \& Irion, 2016; Nüsslein-Völlard \& Singh, 2017). Cell adhesion

510 processes are illustrated by the numerous calcium-dependent (proto)cadherin genes found in

511 this study (CDH4, FAT1, and PCDH genes), as well as integrins (ITGAV) (Tables 2 and S4).

512 Protocadherins (e.g. PCDH10A, PCDHAC2) are essential to fish skin patterning (e.g.

513 Williams, Hsu, Rossi, \& Artinger, 2018; Du et al., 2019).

514 Each association method reported classical candidate genes associated to

515 pigmentation. The RDA reported the above-mentioned (proto)cadherins, but also the ZIC4 or

516 SLC7A11 genes. ZIC4 participates to the dorso-ventral patterning of medaka (Ohtsuka et al., 
517 2004). The observed trait association with SLC7A11 - a gene controlling pheomelanin

518 production in mammals (Chintala et al., 2005) - is another report in fish after carp (Cyprinus

519 carpio; Xu et al., 2014; Jiang et al., 2014) and the 'red' tilapia (Zhu et al., 2016; Wang et al.,

520 2019). GWAS detected some classical players of pigmentation and body colouration in

521 vertebrates (e.g. SOX10, PEML, SLC45A2), including fish (Schonthaler et al., 2005; Hou,

522 Arnheiter, \& Pavan, 2006; Kelsh et al., 2009; Singh \& Nüsslein-Vollard, 2015). Indeed,

523 SOX10 influences colour patterning during zebrafish development (Elworthy, Lister, Carney,

524 Raible, \& Kelsh, 2003; Greenhill, Rocco, Vibert, Nikaido, \& Kelsh, 2011; Nüsslein-Vollard

$525 \&$ Singh, 2017). SLC45A2 is involved in proton-transport and osmoregulation of

526 melanosomes resulting in colour dilution as observed in medaka (Fukamachi, Shimada, \&

527 Shima, 2001) and other organisms (e.g. Xu et al., 2013; Adhikari et al., 2019; Sevane, Sanz,

528 \& Dunner, 2019). PEML (premelanosome protein) contributes to eumelanin deposition and

529 colour dilution in tetrapods (Raposo \& Marks, 2007; Ishishita et al., 2018), and found to be

530 involved in colouration of the koi carp (Luo et al., 2019) and a cichlid (Ahi \& Sfec, 2017).

531 Finally, few CPLs are associated to genes involved in background colour adaptation

532 (GABRA2, gamma-aminobutyric acid receptor subunit alpha-2-like; Bertolesi, Vazhappill,

533 Hehr, \& McFarlane, 2016), or light-induced colour change (MTRR, methionine synthase

534 reductase-like; Jones et al., 2018; FGFR1, fibroblast growth factor receptor-like 1; Czyz,

535 2019). FGF signaling is essential to the developmental patterning of skin and scales in fish

536 (Aman, Fulbright, \& Parichy, 2018), but also eyespots of butterfly wings (Özsu \& Monteiro,

537 2017). This raises interesting questions regarding the conservation of mechanisms involved in

538 spot formation in different developmental contexts.

539 Overall, results established for the brown trout identified both key genes and an array

540 of far less-known genes involved in biological and molecular processes related to the

541 regulation of colour and skin pigmentation patterning. 


\section{3 - A HIGHLY POLYGENIC ARCHITECTURE WITH A ROLE FOR DRIFT}

544 With 337 independent CPLs distributed over 35 LGs and a fraction of them with well-

545 established relationships in modulating colour and pigmentation patterns, a polygenic

546 architecture of body colour patterning is satisfied in the case of brown trout. Informative

547 CPLs participating to genomic architecture of pigmentation in trout are shared in both coding

548 and regulatory regions. This partitioning is now often reported in the literature (e.g. She \&

549 Jarosz, 2018), but still remains relatively poorly investigated in fish (Peichel \& Marques,

550 2017, but see Jones et al., 2012). Within pigmentation studies, literature emphasizes both the

551 relative roles of coding (Protas \& Patel, 2008; Uy et al., 2016) and regulatory variation to

552 limit pleiotropic costs during colour pattern establishment and evolution (Larter, Dunbar-

553 Wallis, Berardi, \& Smith, 2018; Toomey et al., 2018). More coding changes than loci

554 dispersed in regions that might be the basis of regulatory changes were detected in trout, but,

555 due to the reduced representation of the genome provided by ddRAD sequencing, it is

556 difficult to appreciate the relevance of this observation. It might be simply due to the choice

557 of restriction enzymes that returned a peculiar genomic distribution of CPLs. Furthermore, we

558 provided only a loose definition of upstream or downstream regulatory regions (a $25 \mathrm{~kb}$

559 window) that, undoubtedly, has to be refined in further investigations to better decipher, e.g.,

560 cis-regulatory processes.

This polygenic architecture contrasts with former studies that supported oligogenic

562 models or showed the likely presence of few major QTLs in trout and salmonids (Blanc et al.,

563 1982, 1994; Boulding et al., 2008; Colihueque, 2010), but also in other fish species $(n<8$

564 QTLs; Borowsky \& Wilkens, 2002; Miller et al., 2007; Magalhaes \& Seehausen, 2010;

565 Greenwood et al., 2011; Malek et al., 2012; O'Quin et al., 2013; Yong et al., 2015). However,

566 few QTLs are considered not sufficient to explain all causal variation for pigmentation 
567 differences (Greenwood et al., 2011) and comparison with our study should be carefully

568 considered. First, we did not use fish from controlled crossing experiments and our ability to 569 detect any QTL is null. Second, we did not focus on a given body part (e.g. fin) or a 570 pigmentation character (stripe, bars, belly spots) as done in other studies (e.g. Ahi \& Sfec, 571 2017; Roberts et al., 2017), including trout (red spots in Blanc et al., 1994). We explored the 572 complexity in trout pigmentation in order to detect the most important body pattern-related 573 variables relevant to our samples. This automatically increased the panel of loci involved in 574 body colour pigmentation, and, as in this study, when more pigmentation traits were 575 considered, the number of pigmentation-related QTLs was found far higher and distributed 576 over more LGs than when studying only one or few traits $(n>20$; Tripathi et al., 2009; 577 Albertson et al., 2014). was present (Protas, Conrad, Gross, Tabin, \& Borowsky, 2007), and drift is common in trout 580 because of small local effective population sizes $\left(N_{e}\right)$ (e.g. Palm, Laikre, Jorde, \& Ryman, 581 2003; Charlier, Laikre, \& Ryman, 2012). This relies on the classical contrast between the 582 quantitative trait nucleotide (QTNs) and the infinitesimal models of trait variation (e.g. 583 Rockman, 2012). When stochastic processes are of prime importance, small infinitesimal 584 segregate in many genomic regions and might be recruited in the mechanisms and 585 programmes of leading to trait variation (Rockman, 2012). This may translate to a 586 genomically diffuse information to specific phenotypes at the local population level as 587 observed in trout. This is illustrated by loci associated to RDA axis 2 that are population 588 specific (Upper Orb River) and concern peculiar trait associations. The highly polytypic 589 brown trout may illustrate one intermediate situation, in which some master genes are 590 detected at the clade level by both GWAS and RDA and are associated to recognised spotting 591 traits, while 'small players' mostly detected by RDA illustrate patterns specific to local 
592 populations, more locally expressed by other traits (L. Lat, Fr.P). If the big picture provided

593 by master genes should be investigated further, 'small players' cannot be ignored.

\section{4 - RDA: A NEGLECTED METHOD TO SCREEN FOR GENOTYPE-PHENOTYPE ASSOCIATIONS}

596 Our findings illustrate the ability to investigate genotype-phenotype associations with a

597 constrained ordination method like RDA associated to accurate modeling of phenotypic

598 variables. Jombart, Pontier and Dufour (2009) already mentioned that RDA was neglected in

599 association studies despite now recognized desirable properties to limit false positives

600 (Capblanc, Luu, Blum, \& Bazin, 2018; Forester et al., 2018) and robustness to recombination

601 rate variation (Lotterhos, 2019). Effectively, the use of RDA to investigate genotype-

602 phenotype associations remains seldom (Talbot et al., 2017; Vangestel, Eckert, Wegrzyn, St.

603 Clair, \& Neale, 2018; Carvalho et al., 2020), while it became a standard in genotype-

604 environment association studies (Forester, Lasky, Wagner, \& Urban, 2018), including trout

605 (Bekkevold et al., 2019). Basically, RDA allowed for distinguishing the part of variation

606 collectively explained by RAD-loci and independent pigmentation variables ( $35 \%$ of

607 observed trait variation). A large portion of observed pigmentation might be noise or be

608 environment-dependent. Studies in salmon (Jørgensen et al. 2018) and trout (Westley et al.,

609 2013) showed that plasticity may indeed prevail in explaining pigmentation patterns. While it

610 discards markers under balancing selection, a beneficial feature of RDA is to possibly focus

611 on SNPs that may explain for causal variation with at least one phenotypic variable, and not

612 only using outlier loci with the highest $F_{\mathrm{ST}}$ values, but without demonstrated association to a

613 phenotype. For example, in a study dealing with pigmentation variation, Neethiraj, Hornett,

614 Hill, and Wheat (2017) used genome scans tools to identify outlier loci, then a posteriori

615 searched for association of these loci with pigmentation. If RDA remains affected by some

616 false positives as are genome scans, it certainly targets more relevant loci as illustrated by the 
617 high number of CPLs retrieved from the literature in this study. Gautier (2015) proposed a

618 model based on Bayesian outlier detection model that may use a color variable as a covariate,

619 but it is limited so far to a single covariate when model-based selection prior to RDA might

620 allow for considering several ones concurrently. Adding on Jombart et al. (2009), RDA or

621 related methods (e.g canonical correlation analysis, Porter \& O'Reilly, 2017) deserve more

622 attention in association studies.

$624 \quad 4.5$ - IMPLICATIONS FOR MANAGEMENT

625 Contrary to birds (Hanna et al., 2018; Billerman et al., 2019) or mammals (e.g. Anderson et 626 al., 2009; Fulgione et al., 2016), how differences in body pigmentation are related to 627 differentiation and admixture was poorly studied in fish and was not related to conservation 628 and management issues (Malek et al., 2012; Meier et al., 2018, but see Boulding et al., 2008).

629 Using mitochondrial and allozymic markers, Aparicio et al. (2005) paved the way to use 630 pigmentation as a proxy of admixture between Atlantic and Mediterranean trout and to 631 address such issues. Indeed, body pigmentation patterns are often important to anglers and 632 managers to characterize local trout populations and their "integrity". Earlier studies 633 addressing this issue using old-generation markers indicated that pigmentation might 634 represent such a proxy (Mezzera et al., 1997; Aparicio et al., 2005; see Delling et al., 2000 for 635 S. t. marmoratus), but this issue was not addressed with SNPs. In this study, RDA showed 636 that 'late backcrossed' individuals clustered very close from the local Mediterranean hatchery 637 strain and wild individuals of the Gravezon River that were used to seed this strain. This 638 suggests that the pigmentation pattern of these latter individuals came back close to the local 639 Mediterranean patterns and that counter selection of Atlantic pigmentation alleles or other 640 changes (e.g. Endler, Betancourt, Nolte, \& Schlötterer, 2016) occurred. However, different 641 rankings in assignment between this study for CPLs and the full RAD-loci data set (Leitwein 
642 et al., 2018) also suggest that this set of CPLs is not a proxy of genome-wide admixture in this

643 catchment. Managers could build a policy based on wild-caught individuals that exhibit the

644 'local pigmentation' whereas trout remain largely admixed with foreign alleles. If this

645 mismatch between rankings is due to neutral alleles, admixture would hopefully not constrain

646 the adaptive potential of populations, and pigmentation-based management policies that limit

647 the genotyping costs be sufficient. On the contrary, if a mismatch occurs and that CPLs do not

648 mirror admixture at locally-adapted fitness effect loci, using pigmentation as a proxy of local

649 genetic integrity alone might be at risk despite apparent counter-selection. Distinguishing

650 between these situations is a difficult task, but, at that time, heavy reliance on the 'local is

651 best' paradigm (i.e. considering that individuals presenting the 'local' phenotype are more

652 adapted to local conditions) might be harmful for population fitness (Broadhurst et al., 2008;

653 Kronenberger et al., 2018). We are aware that the list of CPLs we propose is a list of

654 candidate markers that has to be refine for further testing against genome-wide admixture, but,

655 in the meantime, managers should adopt a precautionary approach when evaluating

656 population 'integrity' based on body pigmentation.

\section{$657 \quad 4.6$ - LIMITS AND FUTURE DIRECTIONS}

658 While providing strong results, comparisons using individuals from more natural populations, 659 clades and/or subspecies within the S. trutta complex remain necessary in order to better 660 investigate and elucidate the evolutionary history of trout regarding pigmentation patterns and 661 to refine the CPL list. DdRADseq used in this study provides a reduced genome 662 representation targeting only a tiny portion of the genome that is considered either to 663 successfully target (Belsford et al., 2017), or miss important loci responsible for pigmentation 664 patterns (Gauthier et al., 2020). Thus, further RNA sequencing or gene expression studies, 665 together with more standard association studies in control settings that, as for other traits (e.g. 666 Sinclair-Waters et al., 2020), may provide estimates of QTL number, variation in locus effect 
667 sizes and more accurately pointing key master genes seem necessary to improve findings.

668 However, the particular settings of many natural trout populations (low $N_{e}$, high genetic drift

669 and reduced gene flow) have to be taken into account to explain pigmentation diversity

670 observed in the wild. Pigmentation issues represent one outstanding case to investigate

671 genotype-phenotype-environment relationships, and increasing knowledge on such

672 relationships is crucial in salmonid conservation (Waples et al., 2020). As thousands of trout

673 pictures are taken each year and tissue samples might be easily collected, the development of

674 conservation phenogenomics programmes involving scientists and practitioners should be 675 motivated.

676

677 ACKNOWLEDGEMENTS

678 This work benefited from the Montpellier Bioinformatics Biodiversity (MBB) platform from 679 the LabEx CeMEB, an ANR "Investissements d'Avenir" program (ANR-10-LABX-04-01). J.

680 Pouzadoux and A. Jourdan are acknowledged for inputs. ML was partly supported by a grant 681 from LabEx CeMEB.

682

683

684

685

686

687

688

689

690

691

\section{DATA ACCESSIBILITY}

Genomic data are from Leitwein et al. (2018) and available at NCBI Short Read Archive under the study accession SRP136716. The final VCF and the PLINK files for S. trutta LGs are available under the study accessions SRZ187687 and SRZ187688. Upon acceptance, trout pictures and phenotypic data will be deposited on Dryad or another repository. 
692 TV, ML and BG analyzed data and drafted the manuscript. JML acquired phenotypic data.

693 ED provided support to molecular data analysis. ML, PB and BG designed the study. All

694 authors revised drafts and approved the final version.

\section{REFERENCES}

699

700

701

702

703

704

705

706

707

708

709

710

711

712

713

714

715

716

717

718

719

720

721

722

723

724

725

726

727

728

729

730

731

732

733

734

Adhikari, K., Mendoza-Revilla, J., Sohail A., Fuentes-Guajardo, M., Lampert, J., Chacon-Duque, J. C., ... RuizLinares, A. (2019). A GWAS in Latin Americans highlights the convergent evolution of lighter skin pigmentation in Eurasia. Nature Communications, 10(1), 358. doi: 10.1038/s41467-018-08147-0

Ahi, E. P., \& Sefc. K. M. (2017). A gene expression study of dorso-ventrally restricted pigment pattern in adult fins of Neolamprologus meeli, an African cichlid species. PeerJ, 5, e2843. doi: 10.7717/peerj.2843

Albertson, R. C., Powder, K. E., Hu, Y., Coyle, K. P., Roberts, R. B., \& Parsons K. J. (2014). Genetic basis of continuous variation in the levels and modular inheritance of pigmentation in cichlid fishes. Molecular Ecology, 23(21), 5135-5150. doi: 10.1111/mec.12900

Aman, A. J., Fulbright, A. N., \& Parichy D. M. (2018). Wnt/ $\beta$-catenin regulates an ancient signaling network during zebrafish scale development. Elife, 7, e37001. doi: 10.7554/eLife.37001

Amsen, E. M., Pham, N., Pak, Y., \& Rotin, D. (2006). The guanine nucleotide exchange factor CNrasGEF regulates melanogenesis and cell survival in melanoma cells. Journal of Biological Chemistry, 281(1), 121128. doi: 10.1074/jbc.M507595200

Anderson, T. M., vonHoldt, B. M., Candille, S. I., Musiani, M., Greco, C., Stahler, D. R., ... Barsh, G. S. (2009). Molecular and evolutionary history of melanism in North American gray wolves. Science, 323, 1339-1343. doi: $10.1126 /$ science. 1165448

Aparicio, E., García-Berthou, E., Araguas, R. M., Martinez, P., \& Garcia-Marin, J. L. (2005). Body pigmentation pattern to assess introgression by hatchery stocks in native Salmo trutta from Mediterranean streams. Journal of Fish Biology, 67(4), 937-949. doi: 10.1111/j.0022-1112.2005.00794.x

Arnoult, L., Su, K. F., Manoel, D., Minervino, C., Magriña, J., Gompel, J., \& Prud'Homme, B. (2013). Emergence and diversification of fly pigmentation through evolution of a gene regulatory module. Science, 339, 1423-1426. doi: 10.1126/science.1233749

Aspengren, S., Hedberg, D., Sköld, H. N., \& Wallin, M. (2009). New insights into melanosome transport in vertebrate pigment cells. International Review of Cell and Molecular Biology, 272, 245-302. doi: 10.1016/S1937-6448(08)01606-7

Auld, H.L., Noakes, D.L.G., \& Banks, M.A. (2019). Advancing mate choice studies in salmonids. Reviews in Fish Biology and Fisheries, 29, 249-276. doi: 10.1007/s11160-019-09551-5

Beauvais., A, Erickson, C. A., Goins, T., Craig, S. E., Humphries, M. J., Thiery, J-P., \& Dufour, S. (1995). Changes in the fibronectin-specific integrin expression pattern modify the migratory behavior of sarcoma $\mathrm{S} 180$ cells in vitro and in the embryonic environment. Journal of Cell Biology, 128(4), 699-713. doi: $10.1083 /$ jcb.128.4.699

Bekkevold, D., Höjesjö, J, Nielsen, E. E., Aldvén, D., Damm Als, T., Sodeland, M., ... Hansen, M. M. (2019). Northern European Salmo trutta (L.) populations are genetically divergent across geographical regions and environmental gradients. Evolutionary Applications, 13(2), 400-416. doi: 10.1111/eva.12877

Bellono, N. W., \& Oancea, E. V. (2014). Ion transport in pigmentation. Archives of Biochemistry and Biophysics, 563, 35-41. doi: 10.1016/j.abb.2014.06.020 
735

736

737

738

739

740

741

742

743

744

745

746

747

748

749

750

751

752

753

754

755

756

757

758

759

760

761

762

763

764

765

766

767

768

769

770

771

772

773

774

775

776

777

778

779

780

781

782
Berg, J. J., \& Coop, G. 2014. A population genetic signal of polygenic adaptation. PLoS Genetics, 10(8), e1004412. doi: 10.1371/journal.pgen.1004412

Bernatchez, L. (2001). The evolutionary history of brown trout (Salmo trutta L.) inferred from phylogeographic, nested clade, and mismatch analyses of mitochondrial DNA variation. Evolution, 55, 351-379. doi: 10.1111/j.0014-3820.2001.tb01300.x

Bertolesi, G. E., Vazhappilly, S. T., Hehr, C. L., \& McFarlane, S. (2016). Pharmacological induction of skin pigmentation unveils the neuroendocrine circuit regulated by light. Pigment Cell and Melanoma Research, 29, 186-198. doi: 10.1111/pcmr.12442

Blanc, J-M., Poisson, H., \& Vibert R. (1982). Variabilité génétique de la ponctuation noire sur la truitelle Fario (Salmo trutta L.). Annales de Génétique et de Sélection Animale, 14, 225-236

Blanc, J-M., Chevassus, B., \& Krieg, F. (1994). Inheritance of the number of red spots on the skin of the brown trout. Aquatic Living Resources, 7, 133-136. doi: 10.1051/alr:1994016

Blanc, J-M., Poisson, H., \& Quillet, E. (2006). A blue variant in the rainbow trout, Oncorhynchus mykiss Walbaum. Journal of Heredity, 97, 89-93. doi: 10.1093/jhered/esj010

Bian, C., Hu, Y., Ravi, V., Kuznetsova, I. S., Shen, X., Mu, X.,... Shi, Q. (2016). The Asian arowana (Scleropages formosus) genome provides new insights into the evolution of an early lineage of teleosts. Scientific Reports, 6, 24501. doi:10.1038/srep24501

Billerman, S. M., Cicero, C., Bowie, R. C. K., \& Carling, M. D. (2019). Phenotypic and genetic introgression across a moving woodpecker hybrid zone. Molecular Ecology, 28, 1692-1708. doi: 10.1111/mec.15043

Blanchet, F. G., Legendre, P., \& Borcard, D. (2008). Forward selection of explanatory variables. Ecology, 89, 2623-2632. doi: 10.1890/07-0986.1

Bohling, J., Haffray, P., \& Berrebi, P. (2016). Genetic diversity and population structure of domestic brown trout (Salmo trutta) in France. Aquaculture 462: 1-9. doi: 10.1016/j.aquaculture.2016.04.013

Borowsky, R., \& Wilkens, H. 2002. Mapping a cave fish genome: polygenic systems and regressive evolution. Journal of Heredity, 93(1), 19-21. doi: 10.1093/jhered/93.1.19

Boulding, E. G., Culling, M., Glebe, B., Berg, P.R., Lien, S., \& Moen T. (2008). Conservation genomics of Atlantic salmon: SNPs associated with QTLs for adaptive traits in parr from four trans-Atlantic backcrosses. Heredity, 101, 381-391. doi: 10.1038/hdy.2008.67

Braasch, I., Brunet, F., Volff, J-N., \& Schartl, M. (2009). Pigmentation pathway evolution after whole-genome duplication in fish. Genome Biology and Evolution, 1, 479-493. doi: 10.1093/gbe/evp050

Brännäs, E., Backström, T., Nilsson, J., Carlberg, H., Stien, L. H., \& Magnhagen, C. (2016). Distinguishing Arctic charr with different stress coping styles by visual screening of spottiness - reliability and consistency over time. Journal of Zoology, 300, 213-220. doi: 10.1111/jzo.12374

Brelsford, A., Toews, D. P. L., \& Irwin D. E. (2017). Admixture mapping in a hybrid zone reveals loci associated with avian feather coloration. Proceedings: Biological Sciences, 284, 20171106. doi: 10.1098/rspb.2017.1106

Brien, M. N., Enciso-Romero, J., Parnell, A. J., Salazar, P. A., Morochz, C., Chala, D., ... Nadeau, N. J. (2019). Phenotypic variation in Heliconius erato crosses shows that iridescent structural colour is sex-linked and controlled by multiple genes. Interface Focus, 9, 20180047. doi:10.1098/rsfs.2018.0047

Broadhurst, L. M., Lowe, A., Coates, D. J., Cunningham, S. A., McDonald, M., Vesk, P. A., \& Yates, C. (2008). Seed supply for broadscale restoration: maximizing evolutionary potential. Evolutionary Applications, 1: 587-597. doi: 10.1111/j.1752-4571.2008.00045.x

Budy, P., Thiede G. P., Lobón-Cerviá, J., Gonzales, G., McHugh, P., McIntosh, A., ... Jellyman, P. (2013). Limitation and facilitation of one of the world's most invasive fish: an intercontinental comparison. Ecology, 94, 356-367. doi: 10.2307/23435983

Bush, W. D., \& Simon, J. D. (2007). Quantification of $\mathrm{Ca}^{2+}$ binding to melanin supports the hypothesis that melanosomes serve a functional role in regulating calcium homeostasis. Pigment Cell Research, 20, 134-139. doi: 10.1111/j.1600-0749.2007.00362.x 
783

784

785

786

787

788

789

790

791

792

793

794

795

796

797

798

799

800

801

802

803

804

805

806

807

808

809

810

811

812

813

814

815

816

817

818

819

820

821

822

823

824

825

826

827

828

829

830

831

832

833

Cal, L., Suarez-Bregua, P., Braasch, I., Irion, U., Kelsh, R., Cerda-Reveter, M., \& Rotllant, J. (2019). Loss-offunction mutations in the melanocortin 1 receptor cause disruption of dorso-ventral countershading in teleost fish. Pigment Cell and Melanoma Research, 32, 817-828. doi: 10.1111/pcmr.12806

Capblancq, T., Luu, K., Blum, M. G. B., \& Bazin, E. (2018). Evaluation of redundancy analysis to identify signatures of local adaptation. Molecular Ecology Resources, 18, 1223-1233. doi:10.1111/1755-0998.12906

Carvalho, C. S., Forester, B. R., Mitre, S. K., Alves, A., Imperatriz-Fonseca, V. L., Ramos, S. J., ... Jaffé, R. (2020). Combining genotype, phenotype, and environmental data to delineate site-adjusted provenance strategies for ecological restoration. Molecular Ecology Resources , doi:10.1111/1755-0998.13191

Ceinos, R. M., Guillot, R., Kelsh, R. N., Cerdá-Reverter, J. M., \& Rotllant, J. (2015). Pigment patterns in adult fish result from superimposition of two largely independent pigmentation mechanisms. Pigment Cell and Melanoma Research, 28(2), 196-209. doi: 10.1111/pcmr.12335

Chan, I. Z. W., Stevens, M., \& Tood, P. A. (2019). PAT-GeOM: a software package for analysis of animal colour patterns. Methods in Ecology and Evolution, 10(4), 591-600. doi: 10.1111/2041-210X.13131

Charlier, J., Laikre, L., \& Ryman, N. (2012). Genetic monitoring reveals temporal stability over 30 years in a small, lake-resident brown trout population. Heredity, 109(4), 246-253. doi:10.1038/hdy.2012.36

Cheli, Y., Ohanna, M., Ballotti, R., \& Bertolotto, C. (2010). Fifteen-year quest for microphthalmia-associated transcription factor target genes. Pigment Cell and Melanoma Research, 23(1), 27-40. doi: 10.1111/j.1755148X.2009.00653.X

Chintala, S., Li, W., Lamoreux, M. L., Ito, S., Wakamatsu, K., Sviderskaya, E. V., ... Swank, R. T. (2005). Slc7all gene controls production of pheomelanin pigment and proliferation of cultured cells. Proceedings of the National Academy of Sciences of the USA, 102(31), 10964-10969. doi:10.1073/pnas.0502856102

Cichorek, M., Wachulska, M., Stasiewicz, A., \& Tymińska, A. (2013). Skin melanocytes: biology and development. Postepy Dermatology and Alergology, 30(1), 30-41. doi: 10.5114/pdia.2013.33376

Cieslak, M., Reissmann, M., Hofreiter, M., \& Ludwig, A. (2011). Colours of domestication. Biological Reviews of the Cambridge Philosophical Society, 86(4), 885-899. doi: 10.1111/j.1469-185X.2011.00177.x

Colihueque, N. (2010). Genetics of salmonid skin pigmentation: clues and prospects for improving the external appearance of farmed salmonids. Reviews in Fish Biology and Fisheries, 20, 71-86. doi: 10.1007/s11160009-9121-6

Crawford, N. G., Kelly, D. E., Hansen M. E. B., Beltrame, M. H. Fan, S., Bowman, S. L., ... Tishkoff, S. A. (2017). Loci associated with skin pigmentation identified in African populations. Science, 358, eaan8433. doi:10.1126/science.aan8433

Croucher, P. J., Oxford, G. S., Lam, A., \& Gillespie, R. G. 2011. Stabilizing selection maintains exuberant colour polymorphism in the spider Theridion californicum (Araneae, Theridiidae). Molecular Ecology, 20(2), 206-218. doi:10.1111/j.1365-294X.2010.04941.x

Cuthill, I. C., Allen, W. L., Arbuckle, K., Caspers, B., Chaplin, G., Hauber, M. E., ... Caro, T. (2017). The biology of color. Science, 357, ean0221. doi:10.1126/science.aan0221

Czyz, M. (2019). Fibroblast growth factor receptor signaling in skin cancers. Cells, 8(6), 540. doi: $10.3390 /$ cells 8060540

da Silva Romero, A. R., Siquera, F., Santiago, G. G., Correia de Almeida Regitano, L., Dorta de Souza Junior, M., de Ameida Torres Junior, R. A., ... Barufatti Grisolia, A. (2018). Prospecting genes associated with navel length, coat and scrotal circumference traits in Canchim cattle. Livestock Science, 210, 33-38. doi: 10.1016/j.livsci.2018.02.004

Daya, M., van der Merwe, L., Gignoux, C. R., van Helden, P. D., Möller, M., \& Hoal, E. G. (2014). Using multiway admixture mapping to elucidate TB susceptibility in the South African coloured population. BMC Genomics, 15(1), 1021. doi: 10.1186/1471-2164-15-1021

Delling, B., Crivelli, A. J., Rubin, J-F., \& Berrebi, P. (2000). Morphological variation in hybrids between Salmo marmoratus and alien Salmo species in the Volarja stream, Soca River basin, Slovenia. Journal of Fish Biology, 57, 1199-1212. doi: 10.1006/jfbi.2000.1383

Denecker, G., Vandamme, N., Akay, O., Koludrovic, D., Taminau, J., Lemaire, K., ... Berx, G. (2014). Identification of a ZEB2-MITF-ZEB1 transcriptional network that controls melanogenesis and melanoma progression. Cell Death and Differentiation, 21(8), 1250-1261. doi:10.1038/cdd.2014.44 
834

835

836

837

838

839

840

841

842

843

844

845

846

847

848

849

850

851

852

853

854

855

856

857

858

859

860

861

862

863

864

865

866

867

868

869

870

871

872

873

874

875

876

877

878

879

880

881

882

883

884

Ding, B., Patterson, E. L., Holalu, S. V., Li, J., Johnson, G. A., Stanley, L. E., ... Yuan, Y-W. (2020). Two MYB proteins in a self-organizing activator-inhibitor system produce spotted pigmentation patterns. Current Biology, 30(5), 802-814.e8. doi:10.1016/j.cub.2019.12.067

Djurdjevič, I., Furmanek, T., Miyazawa, S., \& Sušnik Bajec, S. (2019). Comparative transcriptome analysis of trout skin pigment cells. BMC Genomics, 20(1), 359. doi:10.1186/s12864-019-5714-1

Du, J., Chen, X., Wang, J., Chen, H., Yue, W. Lu, G., \& Wang, C. (2019). Comparative skin transcriptome of two Oujiang color common carp (Cyprinus carpio var. color) varieties. Fish Physiology and Biochemistry, 45(1), 177-185. doi: 10.1007/s10695-018-0551-8

Dudbridge, F., \& Gusnanto, A. (2008). Estimation of significance thresholds for genomewide association scans. Genetic Epidemiology, 32(3), 227-234. doi: 10.1002/gepi.20297

Duchi, A. (2018). Flank spot number and its significance for systematics, taxonomy and conservation of the near-threatened Mediterranean trout Salmo cettii: evidence from a genetically pure population. Journal of Fish Biology, 92, 254-260. doi:10.1111/jfb.13492

Elworthy, S., Lister, J.A., Carney, T. J., Raible, D. W., \& Kelsh, R. N. (2003). Transcriptional regulation of mitfa accounts for the sox10 requirement in zebrafish melanophore development. Development, 130(12), 28092818. doi: $10.1242 / \mathrm{dev} .00461$

Elliott, J. M. (1989). Wild brown trout Salmo trutta: an important national and international resource. Freshwater Biology, 21, 1-5. doi: 10.1111/j.1365-2427.1989.tb01343.x

Endler, J. A., Cole, G. L., \& Kranz, A. M. (2018). Boundary strength analysis: combining colour pattern geometry and coloured patch visual properties for use in predicting behaviour and fitness. Methods in Ecology and Evolution, 9, 2334-2448. doi: 10.1111/2041-210X.13073

Endler, L., Betancourt, A. J., Nolte, V., \& Schlötterer, C. (2016). Reconciling differences in pool-GWAS between populations: A case study of female abdominal pigmentation in Drosophila melanogaster. Genetics, 202, 843-855.

Eom, D. S., Bain, E. J., Patterson, L. B., Grout, M. E., \& Parichy, D. M. (2015). Long-distance communication by specialized cellular projections during pigment pattern development and evolution. Elife, 4, e12401. doi:10.7554/eLife.12401

Forester, B. R., Lasky, J. R., Wagner, H. H., \& Urban, D. L. (2018). Comparing methods for detecting multilocus adaptation with multivariate genotype-environment associations. Molecular Ecology, 27(9), 2215-2233. doi: $10.1111 / \mathrm{mec} .14584$

Frichot, E., \& Francois, O. (2015). LEA: an R package for Landscape and Ecological Association studies. Methods in Ecology and Evolution, 6(8), 925-929. doi: 10.1111/2041-210X.12382

Friedman, J., Hastie, T., \& Tibshirani, R. (2010). Regularization paths for generalized linear dodels via coordinate descent. Journal of Statistical Softwares, 33(1), 1-22. PMID: 20808728

Fukamachi, S., Shimada, A., \& Shima, A. (2001). Mutations in the gene encoding B, a novel transporter protein, reduce melanin content in medaka. Nature Genetics, 28(4), 381-385. doi: 10.1038/ng584

Fulgione, D., Rippa, D., Buglione, M., Trapanese, M., Petrelli, S., \& Maselli, V. (2016). Unexpected but welcome. Artificially selected traits may increase fitness in wild boar. Evolutionary Applications, 9(6), 769776. doi: 10.1111/eva.12383

Gallagher, S. J., Rambow, F., Kumasaka, M., Champeval, D., Bellacosa, A., Delmas, M., \& Larue, L. (2013). Beta-catenin inhibits melanocyte migration but induces melanoma metastasis. Oncogene, 32(17), 2230-2238. doi: 10.1038/onc.2012.229

Gautier, M. (2015). Genome-wide scan for adaptive divergence and association with population-specific covariates. Genetics, 201(4), 1555-1579. doi: 10.1534/genetics.115.181453

Gauthier, J., de Silva, D. L., Gompert, Z., Whibley, A., Houssin, C., Le Poul, Y., ... Elias, M. 2020. Contrasting genomic and phenotypic outcomes of hybridization between pairs of mimetic butterfly taxa across a suture zone. Molecular Ecology, 29(7), 1328-1343. doi: 10.1111/mec.15403

Ginger, R. S., Askew, S. E., Ogborne, R. M., Wilson, S., Fernadino, D., Dadd, T., ... Green, M. R. (2008). $S L C 24 A 5$ encodes a trans-Golgi network protein with potassium-dependent sodium-calcium exchange activity that regulates human epidermal melanogenesis. Journal of Biological Chemistry, 283(9), 5486-5495. doi:10.1074/jbc.M707521200 
885

886

887

888

889

890

891

892

893

894

895

896

897

898

899

900

901

902

903

904

905

906

907

908

909

910

911

912

913

914

915

916

917

918

919

920

921

922

923

924

925

926

927

928

929

930

931

932

933

934

935

Gramann, A. K., Venkatesan, A. M., Guerin, M., \& Ceol, C. J. (2019). Regulation of zebrafish melanocyte development by ligand-dependent BMP signaling. Elife, 8, e50047. doi: 10.7554/eLife.50047

Greenhill, E. R., Rocco, A., Vibert, L., Nikaido, M., \& Kelsh, R. N. (2011). An iterative genetic and dynamical modelling approach identifies novel features of the gene regulatory network underlying melanocyte development. PLoS Genetics, 7(9), e1002265. doi: 10.1371/journal.pgen.1002265

Greenwood, A. K., Jones, F. C., Chan, Y. F., Brady, S. D., Absher, D. M., Grimwood, J., ... Peichel, C. L. (2011). The genetic basis of divergent pigment patterns in juvenile threespine sticklebacks. Heredity, 107(2), 155-166. doi: 10.1038/hdy.2011.1

Hanna, Z. R., Dumbacher, J. P., Bowie, R. C. K., Henderson, J. B., \& Wall, J. D. (2018). Whole-genome analysis of introgression between the spotted owl and barred owl (Strix occidentalis and Strix varia, respectively; Aves: Strigidae) in western North America. G3, 8(12), 3945-3952. doi: $10.1534 / \mathrm{g} 3.118 .200754$

Heimerl, S., Bosserhoff, A. K., Langmann, T., Ecker, J., \& Schmitz, G. (2007). Mapping ATP-binding cassette transporter gene expression profiles in melanocytes and melanoma cells. Melanoma Research, 17(5), 265273. doi: 10.1097/CMR.0b013e3282a7e0b9

Hellström, A. R., Watt, B., Fard, S. S., Tenza, D., Mannström, P., Narfström, K., ... Andersson, L. (2011). Inactivation of Pmel alters melanosome shape but has only a subtle effect on visible pigmentation. PLoS Genetics, 7(9), e1002285. doi: 10.1371/journal.pgen.1002285

Henning, F., Jones, J. C., Franchini, P., \& Meyer, A. (2013). Transcriptomics of morphological color change in polychromatic Midas cichlids. BMC Genomics, 14, 171. doi: 10.1186/1471-2164-14-171

Henning, F., Lee, H. J., Franchini, P., \& Meyer, A. (2014). Genetic mapping of horizontal stripes in Lake Victoria cichlid fishes: benefits and pitfalls of using RAD markers for dense linkage mapping. Molecular Ecology, 23(21), 5224-5240. doi: 10.1111/mec.12860

Hirobe, T. (2011). How are proliferation and differentiation of melanocytes regulated? Pigment Cell and Melanoma Research, 24(3), 462-478. doi: 10.1111/j.1755-148X.2011.00845.x

Hong, L., \& Simon, J. D. (2007). Current understanding of the binding sites, capacity, affinity, and biological significance of metals in melanin. Journal of Physical Chemistry, B111(28), 7938-7947. doi: $10.1021 / \mathrm{jp} 071439 \mathrm{~h}$

Hou, L., Arnheiter, H., \& Pavan, W. J. (2006). Interspecies difference in the regulation of melanocyte development by SOX10 and MITF. Proceedings of the national Academy of Sciences of the USA, 103(24), 9081-9085. doi: 10.1073/pnas.0603114103

Huang, J. M., \& Hornyak, T. J. (2015). Polycomb group proteins - epigenetic repressors with emerging roles in melanocytes and melanoma. Pigment Cell and Melanoma Research, 28(3), 330-339. doi: $10.1111 / \mathrm{pcmr} .12341$

Hultman, K. A., Bahary, N., Zon, L. I., \& Johnson, S. L. (2007). Gene duplication of the zebrafish kit ligand and partitioning of melanocyte development functions to kit ligand a. PLoS Genetics, 3(1), e17. doi: 10.1371/journal.pgen.0030017

Irion, U., \& Nüsslein-Volhard, C. (2019). The identification of genes involved in the evolution of color patterns in fish. Current Opinion in Genetics and Development, 57, 31-38. doi: 10.1016/j.gde.2019.07.002

Ishishita, S., Takahashi, M., Yamaguchi, K., Kinoshita, K., Nakano, M., Nunome, M., ... Matsuda, Y. (2018). Nonsense mutation in PMEL is associated with yellowish plumage colour phenotype in Japanese quail. Scientific Reports, 8(1), 16732. doi: 10.1038/s41598-018-34827-4

Jacquin, L., Gauthey, Z., Roussille, V., Le Hénaff, M., Tentelier, C., \& Labonne, J. (2017). Melanin in a changing world: brown trout coloration reflects alternative reproductive strategies in variable environments. Behavioral Ecology, 28(6), 1423-1434. doi: 10.1093/beheco/arx102

Jia, Q., Hu, S., Jiao, D., Li, X., Qi, S., \& Fan, R. (2020). Synaptotagmin-4 promotes dendrite extension and melanogenesis in alpaca melanocytes by regulating $\mathrm{Ca}^{2+}$ influx via TRPMI channels. Cell Biochemistry and Functions, 38(3), 275-282. doi: 10.1002/cbf.3465

Jiang., Y, Zhang, S., Xu, J., Feng, J. Mahboob, S., Al-Ghanim, K.A.,... Xu, P. (2014). Comparative transcriptome analysis reveals the genetic basis of skin color variation in common carp. PLoS One, 9(9), e108200. doi: 10.1371/journal.pone.0108200 
936

937

938

939

940

941

942

943

944

945

946

947

948

949

950

951

952

953

954

955

956

957

958

959

960

961

962

963

964

965

966

967

968

969

970

971

972

973

974

975

976

977

978

979

980

981

982

983

984

985

Jin, Y., Andersen, G., Yorgov, D., Ferrara, T. M., Ben, S., Brownson, K. M., ... Spritz, R. A. (2016). Genomewide association studies of autoimmune vitiligo identify 23 new risk loci and highlight key pathways and regulatory variants. Nature Genetics, $48(11)$, 1418-1424. doi: 10.1038/ng.3680

Jombart, T., Pontier, D., \& Dufour, A. B. (2009). Genetic markers in the playground of multivariate analysis. Heredity, 102(4), 330-341. doi: 10.1038/hdy.2008.130

Jones, F. C., Grabherr, M. G., Chan, Y. F., Russell, P., Mauceli, E., Johnson, J., ... Kingsley, D. M. (2012). The genomic basis of adaptive evolution in threespine sticklebacks. Nature, 484, 55-61. doi: 10.1038/nature10944

Jones, P., Lucock, M., Veysey, M., Jablonski, N., Chaplin, G., \& Beckett, E. (2018). Frequency of folate-related polymorphisms varies by skin pigmentation. American Journal of Human Biology, 30(2), 10.1002/ajhb.23079. doi: 10.1002/ajhb.23079

Jørgensen, K. M., Solberg, M. F., Besnier, F., Thorsen, A., Fjelldal, P. J., Skaala, Ø., ..., Glover, K. A. (2018). Judging a salmon by its spots: environmental variation is the primary determinant of spot patterns in Salmo salar. BMC Ecology, 18(1), 14. doi: 10.1186/s12898-018-0170-3

Kang, X., Liu, G., Liu, Y., Xu, Q., Zhang, M., \& Fang, M. (2013). Transcriptome profile at different physiological stages reveals potential mode for curly fleece in Chinese tan sheep. PLoS One, 8(8), e71763. doi: 10.1371/journal.pone.0071763

Kardos, M., Husby, A., McFarlane, S. E., Qvarnström, A., \& Ellegren, H. (2016). Whole-genome resequencing of extreme phenotypes in collared flycatchers highlights the difficulty of detecting quantitative trait loci in natural populations. Molecular Ecology Resources, 16(3), 727-741. doi: 10.1111/1755-0998.12498

Kelsh, R. N., Inoue, C., Momoi, A., Kondo, H., Furutani-Seiki, M., Ozato, K., \& Wakamatsu, Y. (2004). The Tomita collection of medaka pigmentation mutants as a resource for understanding neural crest cell development. Mechanisms of Development, 121(7-8), 841-859. doi: 10.1016/j.mod.2004.01.004

Kelsh, R. N., Harris, M. L., Colanesi, S., \& Erickson, C. A. (2009). Stripes and belly-spots -- a review of pigment cell morphogenesis in vertebrates. Seminars in Cell and Developmental Biology, 20(1), 90-104. doi: $10.1016 /$ j.semcdb.2008.10.001

Kido, K., Sumimoto, H., Asada, S., Okada, S. M., Yaguchi, T., Kawamura, N., ... Kaxakami, Y. (2009). Simultaneous suppression of MITF and BRAF $^{\mathrm{V} 600 \mathrm{E}}$ enhanced inhibition of melanoma cell proliferation. Cancer Science, 100(10), 1863-1869. doi: 10.1111/j.1349-7006.2009.01266.x

Kimura, T., Nagao, Y., Hashimoto, H., Yamamoto-Shiraishi, Y., Yamamoto, S., Yabe, T., ... Naruse, K. (2014). Leucophores are similar to xanthophores in their specification and differentiation processes in medaka. Proceedings of National Academy of Sciences of the USA, 111(20), 7343-7348. doi: 10.1073/pnas.1311254111

Kimura, T., Takehana, Y., \& Naruse, K. (2017). pnp4a is the causal gene of the medaka iridophore mutant guanineless. G3 7(4): 1357-1363. doi:10.1534/g3.117.040675

Kirczuk, L., \& Domagała, J. (2012). Colouration of reciprocal hybrids of salmon (Salmo salar L., 1758) and sea trout (Salmo trutta m. trutta L, 1758) aged $0+$ and $1+$ in the natural conditions. Electronic Journal of Polish Agricultural University, 15(1), 02. available online: http://www.ejpau.media.pl/volume15/issue1/art-02.html

Kittilsen, S., Schjolden, J., Beitnes-Johansen, I., Shaw, J. C., Pottinger, T. G., Sørensen, C., ... Øverli Ø. (2009). Melanin-based skin spots reflect stress responsiveness in salmonid fish. Hormones and Behavior, 56, 292298. doi: 10.1016/j.yhbeh.2009.06.006

Klotz, B., Kneitz, S., Regensburger, M., Hahn, L., Dannemann, M., Kelso, J., ... Schartl, M. (2018). Expression signatures of early-stage and advanced medaka melanomas. Comparative Biochemistry and Physiology C: Toxicology and Pharmacology, 208, 20-28. doi: 10.1016/j.cbpc.2017.11.005

Kocabaş, M., Kayim, M., Can, E., Ateş, M., Kutluyer F., \& Aksu, Ö. (2011). Spotting pattern features in the brown trout (Salmo trutta macrostigma, T., 1954) population. Scientific Research and Essays, 6(23), 50215024 .

Kocabaş, M., Kutluyer F., \& Başçinar N. (2018). Phenotypic differentiation analysis: A case study in hybridizing Çoruh trout (Salmo coruhensis), Rize trout (Salmo rizeensis) and brown trout (Salmo trutta fario). Acta Zoologica, 99(3), 274-280. doi: 10.1111/azo.12211 
986

987

988

989

990

991

992

993

994

995

996

997

998

999

1000

1001

1002

1003

1004

1005

1006

1007

1008

1009

1010

1011

1012

1013

1014

1015

1016

1017

1018

1019

1020

1021

1022

1023

1024

1025

1026

1027

1028

1029

1030

1031

1032

1033

1034

Kon, T., Omori, Y., Fukuta, K., Wada, H., Watanabe, M., Chen, Z., ... Furukawa, T. (2020). The genetic basis of morphological diversity in domesticated goldfish. Current Biology, 30(12), 2260-2274.e6. doi:10.1016/j.cub.2020.04.034

Kottler, V. A., \& Schartl, M. (2018). The colorful sex chromosomes of teleost fish. Genes, 9(5), 233. doi: 10.3390/genes9050233

Kratochwil, C. F., Liang, Y., Gerwin, J., Woltering, J. M., Urban, S., Henning, F., ... Meyer, A. (2018). Agoutirelated peptide 2 facilitates convergent evolution of stripe patterns across cichlid fish radiations. Science, 362, 457-460. doi: 10.1126/science.aao6809

Kronenberger, J. A., Gerberich, J. C., Fitzpatrick, S. W., Broder, E. D., Angeloni, L. M., \& Funk, W. C. (2018). An experimental test of alternative population augmentation scenarios. Conservation Biology, 32(4), 838848. doi: 10.1111/cobi.13076

Lamason, R. L., Mohideen, M. A., Mest, J. R., Wong, A. C., Norton, H. R., Aros, M. C., ... Cheng, K. C. (2005). $S L C 24 A 5$, a putative cation exchanger, affects pigmentation in zebrafish and humans. Science, 310, 17821786. doi: $10.1126 /$ science. 1116238

Largiadèr, C. R., \& Scholl, A. (1996). Genetic introgression between native and introduced brown trout Salmo trutta L. populations in the Rhône River Basin. Molecular Ecology, 5, 417-426. doi: 10.1046/j.1365294X.1996.00099.x

Larter, M., Dunbar-Wallis, A., Berardi, A .E., \& Smith, S. D. (2018). Convergent evolution at the pathway level: predictable regulatory changes during flower color transitions. Molecular Biology and Evolution, 35(9), 2159-2169. doi: 10.1093/molbev/msy117

Lascaux, J-M. (1996). Analyse de la variabilité morphologique de la truite commune (Salmo trutta L.) dans les cours d'eau du bassin pyrénéen méditerranéen (Unpublished doctoral dissertation). Ecole Nationale Supérieure Agronomique de Toulouse, France.

Lee, J. L., \& Streuli, C. H. (2014). Integrins and epithelial cell polarity. Journal of Cell Science, 127(Pt 15), 3217-3225. doi: $10.1242 /$ jcs. 146142

Legendre, P., \& Legendre, L. (2012). Numerical Ecology, 3rd Edition. Amsterdam: Elsevier.

Leitwein, M., Guinand, B., Pouzadoux, J., Desmarais, E., Berrebi, P., Gagnaire, P-A. (2017). A dense brown trout (Salmo trutta) linkage map reveals recent chromosomal rearrangements in the Salmo genus and the impact of selection on linked neutral diversity. G3, 7(4), 1365-1376. doi:10.1534/g3.116.038497

Leitwein, M., Gagnaire, P-A., Desmarais, E., Berrebi, P., \& Guinand B. (2018). Genomic consequences of a recent three-way admixture in supplemented wild brown trout populations revealed by local ancestry tracts. Molecular Ecology 27(17): 3466-3483. doi: 10.1111/mec.14816

Levy, C., Khaled, M., \& Fisher, D. E. (2006). MITF: master regulator of melanocyte development and melanoma oncogene. Trends in Molecular Medicine, 12(9), 406-414. doi: 10.1016/j.molmed.2006.07.008

Lewis, V. M., Saunders, L. M., Larson, T. A., Bain, E. J., Sturiale, S. L., Gur, D., ... Parichy, D. M.. (2019). Fate plasticity and reprogramming in genetically distinct populations of Danio leucophores. Proceedings of the National Academy of Sciences of the USA, 116(24), 11806-11811. doi: 10.1073/pnas.1901021116

Li, Z., Kemppainen, P., Rastas, P., \& Merilä, J. (2018). Linkage disequilibrium clustering-based approach for association mapping with tightly linked genomewide data. Molecular Ecology Resources, 18(4), 809-824. doi: 10.1111/1755-0998.12893

Liang, Y., Gerwin, J., Meyer, A., \& Kratochwil, C. F. (2020). Developmental and cellular basis of vertical bar color patterns in the East African cichlid fish Haplochromis latifasciatus. Frontiers in Cell and Developmental Biology, 8, 62. doi: 10.3389/fcell.2020.00062

Lien, S., Koop, B. F., Sandve, S. R., Miller, J. R., Kent, M. P., Nome, T., ... Davidson, W. S. (2016). The Atlantic salmon genome provides insights into rediploidization. Nature, 533, 200-205. doi: 10.1038/nature 17164

Lindtke, D., Lucek, K., Soria-Carrasco, V., Villoutreix, R., Farkas, T. E., Riesch, R., ... Nosil, P. (2017). Longterm balancing selection on chromosomal variants associated with crypsis in a stick insect. Molecular Ecology, 26(22), 6189-6205. doi:10.1111/mec.14280 
1035

1036

1037

1038

1039

1040

1041

1042

1043

1044

1045

1046

1047

1048

1049

1050

1051

1052

1053

1054

1055

1056

1057

1058

1059

1060

1061

1062

1063

1064

1065

1066

1067

1068

1069

1070

1071

1072

1073

1074

1075

1076

1077

1078

1079

1080

1081

1082

1083

1084

Lorenzoni, M., Carosi, A., Giovannotti, M., La Porta, G., Splendiani, A., \& Caputo Barucchi, V. (2019). Morphological survey as powerful detection tool of pure and local phenotypes in Salmo trutta complex. Knowledge and Management of Aquatic Ecosystems, 420, 48. doi: 10.1051/kmae/2019041

Lorin, T., Brunet, F. G., Laudet, V., \& Volff, J-N. (2018). Teleost fish-specific preferential retention of pigmentation gene-containing families after whole genome duplications in vertebrates. G3, 8(5), 1795-1806. doi: $10.1534 / \mathrm{g} 3.118 .200201$

Lotterhos, K. E. (2019). The effect of neutral recombination variation on genome scans for selection. G3, 9(6), 1851-1867. doi: $10.1534 / \mathrm{g} 3.119 .400088$

Luo, M., Wang, L., Yin, H., Zhu, W., Fu, J., \& Dong, Z. (2019). Integrated analysis of long non-coding RNA and mRNA expression in different colored skin of koi carp. BMC Genomics, 20(1), 515. doi: 10.1186/s12864-019-5894-8

Maan, M. E., \& Sefc, K. M. (2013). Colour variation in cichlid fish: developmental mechanisms, selective pressures and evolutionary consequences. Seminars in Cell and Developmental Biology, 24(6-7), 516-528. doi: 10.1016/j.semcdb.2013.05.003

Magalhaes, I. S., \& Seehausen, O. (2010). Genetics of male nuptial colour divergence between sympatric sister species of a Lake Victoria cichlid fish. Journal of Evolutionary Biology, 23(5), 914-924. doi: 10.1111/j.1420-9101.2010.01960.x

Mahalwar, P., Walderich, B., Singh, A. P., \& Nüsslein-Volhard, C. (2014). Local reorganization of xanthophores fine-tunes and colors the striped pattern of zebrafish. Science, 345, 1362-1364. doi: 10.1126/science. 1254837

Mahalwar, P., Singh, A. P., Fadeev, A., Nüsslein-Volhard, C., \& Irion, U. (2016). Heterotypic interactions regulate cell shape and density during color pattern formation in zebrafish. Biology Open, 5(11), 1680-1690. doi: 10.1242/bio.022251

Malek, T. B., Boughman, J. W., Dworkin, I., \& Peichel, C. L. (2012). Admixture mapping of male nuptial colour and body shape in a recently formed hybrid population of threespine stickleback. Molecular Ecology, 21(21), 5265-5279. doi: 10.1111/j.1365-294X.2012.05660.x

Marie-Orléach, L., Roussel, J-M., Bugeon, J., Tremblay, J., Ombredane, D., \& Evanno, G. (2014). Melaninbased coloration of sneaker male Atlantic salmon is linked to viability and emergence timing of their offspring. Biological Journal of the Linnean Society, 111(1), 126-135. doi: 10.1111/bij.12187

Marin, K., Coon, A., \& Fraser, D. J. (2017). Traditional ecological knowledge reveals the extent of sympatric lake trout diversity and habitat preferences. Ecology and Society, 22(2), 20. doi:10.5751/ES-09345-220220

Meier, J. I., Marques, D. A., Wagner, C. E., Excoffier, L., Seehausen, O. (2018). Genomics of parallel ecological speciation in Lake Victoria cichlids. Molecular Biology and Evolution, 35(6), 1489-1506. doi: 10.1093/molbev/msy051

Mezzera, M., Largiadèr, C. R., \& Scholl A. (1997). Discrimination of native and introduced brown trout in the River Doubs (Rhône drainage) by number and shape of parr marks. Journal of Fish Biology, 50, 672-677. doi: 10.1111/j.1095-8649.1997.tb01959.x

Miller, C. T., Beleza, S., Pollen, A. A., Schluter, D., Kittles, R. A., Shriver, M. D., \& Kingsley, D. M. (2007). Cis-regulatory changes in Kit ligand expression and parallel evolution of pigmentation in sticklebacks and humans. Cell, 131(6), 1179-1189. doi: 10.1016/j.cell.2007.10.055

Miyamoto, K. (2016). Effects of body color luminance and behavioral characteristics on predation risk in salmonid fishes. Hydrobiologia, 783, 249-256. doi: 10.1007/s10750-015-2573-x

Miyazawa, S., Okamoto, M., \& Kondo, S. (2010). Blending of animal colour patterns by hybridization. Nature Communications, 1(6), 66. doi: 10.1038/ncomms1071

Nagao, Y., Takada, H., Miyadai, M., Adachi, T., Seki, R., Kamei, Y., ... Hashimoyo, H. (2018). Distinct interactions of Sox5 and Sox10 in fate specification of pigment cells in medaka and zebrafish. PLoS Genetics, 14(4), e1007260. doi: 10.1371/journal.pgen.1007260

Nazari-Ghadikolaei, A., Mehrabani-Yeganeh, H., Miarei-Aashtiani, S.R., Staiger, E.A., Rashidi, A., \& Huson H. J. (2018). Genome-wide association studies identify candidate genes for coat color and mohair traits in the Iranian Markhoz goat. Frontiers in Genetics, 9, 105. doi: 10.3389/fgene.2018.00105 
1085

1086

1087

1088

1089

1090

1091

1092

1093

1094

1095

1096

1097

1098

1099

1100

1101

1102

1103

1104

1105

1106

1107

1108

1109

1110

1111

1112

1113

1114

1115

1116

1117

1118

1119

1120

1121

1122

1123

1124

1125

1126

1127

1128

1129

1130

1131

1132

1133

1134

Neethiraj, R., Hornett, E.A., Hill, J.A., \& Wheat, C.W. (2017). Investigating the genomic basis of discrete phenotypes using a Pool-Seq-only approach: new insights into the genetics underlying colour variation in diverse taxa. Molecular Ecology, 26(19), 4990-5002. doi: 10.1111/mec.14205

Nilsson, J., Backström, T., Stien, L. H., Carlberg, H. Jeuthe, H., Magnhagen, C., \& Brännäs, E. (2016). Effects of age and rearing environment on genetic parameters of growth and body weight and heritability of skin pigmentation in Arctic charr (Salvelinus alpinus L.). Aquaculture, 453, 67-72. doi: 10.1016/j.aquaculture.2015.11.035

Nüsslein-Volhard, C., \& Singh, A. P. (2017). How fish color their skin: A paradigm for development and evolution of adult patterns: multipotency, plasticity, and cell competition regulate proliferation and spreading of pigment cells in zebrafish coloration. Bioessays, 39(3), 10.1002/bies.201600231. doi:10.1002/bies.201600231

O'Connor, K. I., Metcalfe, N. B., \& Taylor, A. C. (2000). Familiarity influences body darkening in territorial disputes between juvenile salmon. Animal Behaviour, 59(6), 1095-1101. doi: 10.1006/anbe.2000.1401

Ohtsuka, M., Kikuchi, N., Yokoi, H., Kinoshita, M., Wakamatsu, Y., Ozato, K., ... Kimura, M. (2004). Possible roles of zicl and zic4, identified within the medaka Double anal fin (Da) locus, in dorsoventral patterning of the trunk-tail region (related to phenotypes of the Da mutant). Mechanisms of Development, 121(7-8), 873882. doi: 10.1016/j.mod.2004.04.006

Ordway, A.J., Hancuch, K. N., Johnson, W., Wiliams, T. M., \& Rebeiz, M. (2014). The expansion of body coloration involves coordinated evolution in cis and trans within the pigmentation regulatory network of Drosophila prostipennis. Developmental Biology, 392, 431-440. doi: 10.1016/j.ydbio.2014.05.023

O'Quin, C. T., Drilea, A. C., Conte, M. A., \& Kocher T. D. (2013). Mapping of pigmentation QTL on an anchored genome assembly of the cichlid fish, Metriaclima zebra. BMC Genomics, 14, 287. doi: 10.1186/1471-2164-14-287

O'Reilly, P. F., Hoggart, C. J., Pomyen, Y., Calboli, F. C. F., Elliott, P., Jarvelin, M-R., \& Coin, L. J. M. (2012). MultiPhen: joint model of multiple phenotypes can increase discovery in GWAS. PLoS One, 7(5), e34861. doi: 10.1371/journal.pone.0034861

Orteu, A., \& Jiggins, C. D. (2020). The genomics of coloration provides insights into adaptive evolution. Nature Reviews Genetics, 21, 461-475. doi:10.1038/s41576-020-0234-Z

Özsu, N., \& Monteiro, A. (2017). Wound healing, calcium signaling, and other novel pathways are associated with the formation of butterfly eyespots. BMC Genomics, 18(1), 788. doi: 10.1186/s12864-017-4175-7

Pallares, L. F., Harr, B., Turner, L. M., \& Tautz, D. (2014). Use of a natural hybrid zone for genomewide association mapping of craniofacial traits in the house mouse. Molecular Ecology, 23(23), 5756-5770. doi: 10.1111/mec.12968

Palm, S., Laikre, L., Jorde, P.E., \& Ryman, N. (2003). Effective population size and temporal genetic change in resident brown trout (Salmo trutta L.). Conservation Genetics, 4(3), 249-264. doi: 10.1023/A:102406913094

Parichy, D. M. 2006. Evolution of danio pigment pattern development. Heredity, 97(3), 200-210. doi: 10.1038/sj.hdy.6800867

Parichy, D. M., \& Spiewak, J. E. (2015). Origins of adult pigmentation: diversity in pigment stem cell lineages and implications for pattern evolution. Pigment Cell and Melanoma Research, 28(1), 31-50. doi: $10.1111 /$ pcmr. 12332

Patton, E.E., Mitchell, D.L, \& Nairn, R.S. (2010). Genetic and environmental melanoma models in fish. Pigment Cell and Melanoma Research, 23(3), 314-337. doi: 10.1111/j.1755-148X.2010.00693.x

Pavan, W.J., \& Sturm, R.A. (2019). The genetics of human skin and hair pigmentation. Annual Review in Genomics and Human Genetics, 20, 41-72. doi: 10.1146/annurev-genom-083118-015230

Peichel, C. L., \& Marques, D. A. (2017). The genetic and molecular architecture of phenotypic diversity in sticklebacks. Philosophical Transactions of the Royal Society of London B: Biological Sciences, 372(1713), 20150486. doi: 10.1098/rstb.2015.0486

Porter, H. F., \& O'Reilly, P. F. (2017). Multivariate simulation framework reveals performance of multi-trait GWAS methods. Scientific Reports, 7, 38837. doi: 10.1038/srep38837 
1135

1136

1137

1138

1139

1140

1141

1142

1143

1144

1145

1146

1147

1148

1149

1150

1151

1152

1153

1154

1155

1156

1157

1158

1159

1160

1161

1162

1163

1164

1165

1166

1167

1168

1169

1170

1171

1172

1173

1174

1175

1176

1177

1178

1179

1180

1181

1182

1183

Poteaux, C., Berrebi, P. (1997). Intégrité génomique et repeuplements chez la truite commune du bassin méditerranéen. Bulletin Français de la Pêche et de la Pisciculture, 344/345, 309-322. doi : 10.1051/kmae:1997031

Protas, M., Conrad, M., Gross, J. B., Tabin, C., \& Borowsky, R. (2007). Regressive evolution in the Mexican cave tetra, Astyanax mexicanus. Current Biology, 17(5), 452-454. doi: 10.1016/j.cub.2007.01.05

Protas, M. E., Patel, N. H. (2008). Evolution of coloration patterns. Annual Review in Cell and Developmental Biology, 24, 425-446. doi: 10.1146/annurev.cellbio.24.110707.175302

Rammah, C., Gadin, S., Cormier, S., Souilhol, C., Cohen-Tannoudji, M., Panthier, J-J., \& Aubin-Houzelstein, G. (2009). Implication of notchless and strawberry notch homolog 2 genes in melanocyte stem cells homeostasis. Pigment Cell and Melanoma Research, 22, 671. doi: 10.1111/j.1755-148X.2009.00612.x 652 a

Raposo, G., \& Marks, M. S. (2007). Melanosomes - dark organelles enlighten endosomal membrane transport. Nature Reviews in Molecular and Cell Biology, 8(10), 786-797. doi: 10.1038/nrm2258

Rivera-Colón, A. G., Westerman, E. L., Van Belleghem, S. M., Monteiro, A., \& Papa, R. (2020). Multiple loci control eyespot number variation on the hindwings of Bicyclus anynana butterflies. Genetics, 214(4), 10591078. doi: $10.1534 /$ genetics. 120.303059

Roberts, R. B., Moore, E. C., \& Kocher, T. D. (2017). An allelic series at pax7a is associated with colour polymorphism diversity in Lake Malawi cichlid fish. Molecular Ecology, 26(10), 2625-2639. doi: $10.1111 /$ mec. 13975

Roberts, R. B., Ser, J. R., \& Kocher, T. D. (2009). Sexual conflict resolved by invasion of a novel sex determiner in Lake Malawi cichlid fishes. Science, 326, 998-1001. doi: 10.1126/science.1174705

Rockman, M. V. (2012). The QTN program and the alleles that matter for evolution: all that's gold does not glitter. Evolution. 66(1), 1-17. doi:10.1111/j.1558-5646.2011.01486.x

Salis, P., Roux, N., Soulat, O., Lecchini, D., Laudet, V., \& Frédérich, B. (2018). Ontogenetic and phylogenetic simplification during white stripe evolution in clownfishes. BMC Biology, 16(1), 90. doi:10.1186/s12915018-0559-7

San-José, L. M., \& Roulin, A. (2017). Genomics of coloration in natural animal populations. Philosophical Transactions of the Royal Society of London B: Biological Sciences, 372(1724), 20160337. doi: 10.1098/rstb.2016.0337

Santos, M. E., Braasch, I., Boileau, N., Meyer, B. S., Sauteur, L., Böhne, A., ... Salzburger,W. (2014). The evolution of cichlid fish egg-spots is linked with a cis-regulatory change. Nature Communications, 5, 5149. doi: $10.1038 /$ ncomms6149

Santure, A. W., \& Garant, D. (2018). Wild GWAS-association mapping in natural populations. Molecular Ecology Resources, 18(4), 729-738. doi: 10.1111/1755-0998.12901

Sanz, N. (2018). Phylogeographic history of brown trout: a review. In: J. Lobón-Cerviá \& N. Sanz (Eds.), Brown Trout: Biology, Ecology and Management. Pp. 17-63. Oxford: Wiley Ltd.

Schielzeth, H., \& Husby, A. (2014). Challenges and prospects in genome-wide quantitative trait loci mapping of standing genetic variation in natural populations. Annals of the New York Academy of Sciences, 1320, 35-57. doi: $10.1111 /$ nyas. 12397

Schonthaler, H. B., Lampert, J. M., von Lintig, J., Schwarz, H., Geisler, R., \& Neuhauss, S. C. (2005). A mutation in the silver gene leads to defects in melanosome biogenesis and alterations in the visual system in the zebrafish mutant fading vision. Developmental Biology, 284(2), 421-436. doi: 10.1016/j.ydbio.2005.06.001

Schweizer, R.M., Durvasula, A., Smith, J., Vohr, S.H., Stahler, D.R, Galaverni, M., ... Wayne, R.K. (2018). Natural selection and origin of a melanistic allele in North American gray wolves. Molecular Biology and Evolution, 35(5), 1190-1209. doi:10.1093/molbev/msy031

Sevane, N., Sanz, C.R., \& Dunner, S. (2019). Explicit evidence for a missense mutation in exon 4 of SLC45A2 gene causing the pearl coat dilution in horses. Animal Genetics, 50(3), 275-278. doi: 10.1111/age.12784

She, R., \& Jarosz, D.F. (2018). Mapping causal variants with single-nucleotide resolution reveals biochemical drivers of phenotypic change. Cell, 172(3), 478-490.e15. doi: 10.1016/j.cell.2017.12.015 
1184

1185

1186

1187

1188

1189

1190

1191

1192

1193

1194

1195

1196

1197

1198

1199

1200

1201

1202

1203

1204

1205

1206

1207

1208

1209

1210

1211

1212

1213

1214

1215

1216

1217

1218

1219

1220

1221

1222

1223

1224

1225

1226

1227

1228

1229

1230

1231

1232

1233

Schouwey, K., \& Beermann, F. (2008). The Notch pathway: hair graying and pigment cell homeostasis. Histology and Histopathology, 23(5), 609-619. doi: 10.14670/HH-23.609

Shriner, D. (2017). Overview of admixture mapping. Current Protocols in Human Genetics, 94, 1.23.1-1.23.8. doi: $10.1002 /$ cphg.44

Shriver, M. D., Parra, E.J., Dios, S., Bonilla, C., Norton, H., Jovel, C., ... Kittles, R. A. (2003). Skin pigmentation, biogeographical ancestry and admixture mapping. Human Genetics, 112(4), 387-399. doi: 10.1007/s00439-002-0896-y

Sinclair-Waters, M., Ødegård, J., Korsvoll, S. A., Moen, T., Lien, S., Primmer, C. R., \& Barson, N. J. (2020). Beyond large-effect loci: large-scale GWAS reveals a mixed large-effect and polygenic architecture for age at maturity of Atlantic salmon. Genetics Selection Evolution, 52(1), 9 doi: 10.1186/s12711-020-0529-8

Singh, A. P., \& Nüsslein-Volhard, C. (2015). Zebrafish stripes as a model for vertebrate colour pattern formation. Current Biology, 25(2), R81-R92. doi: 10.1016/j.cub.2014.11.013

Singh, S. K., Abbas, W. A., \& Tobin, D. J. (2012). Bone morphogenetic proteins differentially regulate pigmentation in human skin cells. Journal of Cell Science, 125(18), 4306-4319. doi10.1242/jcs.102038

Sivka, U., Snoj, A., Palandačić, A., \& Sušnik Bajec, S. (2013). Identification of candidate genes involved in marble color pattern formation in genus Salmo. Comparative Biochemistry and Physiology D: Genomics and Proteomics, 8(3), 244-249. doi: 10.1016/j.cbd.2013.06.003

Skaala, Ø., \& Jørstad, K. E. (1988). Inheritance of the fine-spotted pigmentation pattern of brown trout. Polskie Archiwum Hydrobiologii, 35, 295-304.

Soong, J., \& Scott, G. (2013). Plexin B1 inhibits MET through direct association and regulates Shp2 expression in melanocytes. Journal of Cell Science, 126(Pt 2), 688-695. doi: 10.1242/jcs.119487

Soong, J., Chen, Y., Shustef, E. M., \& Scott, G. A. (2012). Sema4D, the ligand for Plexin B1, suppresses c-Met activation and migration and promotes melanocyte survival and growth. Journal of Investigative Dermatology, 132(4), 1230-1238. doi: 10.1038/jid.2011.414

Talbot, B., Chen, T. W., Zimmerman, S., Joost, S., Eckert, E. J., Crow, T. M., ... Manel, S. (2017). Combining genotype, phenotype, and environment to infer potential candidate genes. Journal of Heredity, 108(2), 207216. doi: 10.1093/jhered/esw077

Takeda, H., \& Shimada, A. (2010). The art of medaka genetics and genomics: what makes them so unique? Annual Review of Genetics, 44, 217-241. doi: 10.1146/annurev-genet-051710-151001

Toews, D. P. L., Taylor, S. A., Vallender, R., Brelsford, A., Butcher, B. G., Messer, P. W., \& Lovette I. J. (2016). Plumage genes and little else distinguish the genomes of hybridizing warblers. Current Biology, 26, 23132318. doi: 10.1016/j.cub.2016.06.034

Toomey, M. B., Marques, C. I., Andrade, P., Araujo, P. M., Sabatino, S., Gazda, M. A., ... Carneiro, M. (2018). A non-coding region near Follistatin controls head colour polymorphism in the Gouldian finch. Proceedings: Biological Sciences, 285(1888), 20181788. doi: 10.1098/rspb.2018.1788

Tripathi, N., Hoffmann, M., Willing, E. M., Lanz, C., Weigel, D., \& Dreyer, C. (2009). Genetic linkage map of the guppy, Poecilia reticulata, and quantitative trait loci analysis of male size and colour variation. Proceedings: Biological Sciences, 276(1665), 2195-2208. doi: 10.1098/rspb.2008.1930

Uong, A., \& Zon, L. I. (2010). Melanocytes in development and cancer. Journal of Cell Physiology, 222(1), 3841. doi: $10.1002 / \mathrm{jcp} .21935$

Uy, J. A., Cooper, E. A., Cutie, S., Concannon, M. R., Poelstra, J. W., Moyle R. G., \& Filardi, C. E. (2016). Mutations in different pigmentation genes are associated with parallel melanism in island flycatchers. Proceedings: Biological Sciences, 283(1834), 20160731. doi: 10.1098/rspb.2016.0731

Van Belleghem, S.M., Papa, R., Ortiz-Zuazaga, H., Hendrickx, K., Jiggins, C.D., McMillan, W.O., \& Counterman, B.A. (2018). patternize: An R package for quantifying colour pattern variation. Methods in Ecology and Evolution 9(2): 390-398. doi: 10.1111/2041-210X.12853

Vangestel, C., Eckert, A. J., Wegrzyn, J. L., St.Clair, J. B., \& Neale, D. B. (2018). Linking phenotype, genotype and environment to unravel genetic components underlying cold hardiness in coastal Douglas-fir (Pseudotsuga menziesii var. menziesii). Tree Genetics and Genomes, 14, 10. doi: 10.1007/s11295-017-1225$\mathrm{x}$ 
1234

1235

1236

1237

1238

1239

1240

1241

1242

1243

1244

1245

1246

1247

1248

1249

1250

1251

1252

1253

1254

1255

1256

1257

1258

1259

1260

1261

1262

1263

1264

1265

1266

1267

1268

1269

1270

1271

1272

1273

1274

1275
Volkening, A. (2020). Linking genotype, cell behavior, and phenotype: multidisciplinary perspectives with a basis in zebrafish patterns. Current Opinion in Genetics and Development, 63, 78-85. doi:10.1016/j.gde.2020.05.010

Wade, N., Bryant, N.J., Connolly, L. M., Simpson R. J., Luzio, J. P., ... James, D. E.. (2001). Syntaxin 7 complexes with mouse Vps10p tail interactor $1 b$, syntaxin 6, vesicle-associated membrane protein (VAMP)8, and VAMP7 in b16 melanoma cells. Journal of Biological Chemistry, 276(23), 19820-19827. doi: 10.1074/jbc.M010838200

Wang, L. M., Bu, H. Y., Song, F. B., Zhu, W. B., Fu, J. J., \& Dong, Z. J. (2019). Characterization and functional analysis of slc7al1 gene, involved in skin color differentiation in the red tilapia. Comparative Biochemistry and Physiology A: Molecular and Integrative Physiology, 236, 110529. doi: 10.1016/j.cbpa.2019.110529

Wang, Z., Jinnin, M., Kobayashi, Y., Kudo, H., Inoue, K., Nakayama, W., ... Ihn, H. (2015). Mice overexpressing integrin $\alpha v$ in fibroblasts exhibit dermal thinning of the skin. Journal of Dermatological Science, 79(3), 268-278. doi: 10.1016/j.jdermsci.2015.06.008

Waples, R. S., Naish, K. A., \& Primmer, C. R. (2020). Conservation and management of salmon in the age of genomics. Annual Review of Animal Biosciences, 8, 117-143. doi: 10.1146/annurev-animal-021419-083617

Watt, C., Swanson, C., Miller, D., Chen, M. \& May, C. (2017). Social hierarchies override environmental conditions in determining body coloration of brook trout. Journal of Freshwater Ecology, 32(1), 575-580. doi: 10.1080/02705060.2017.1360218

Wedekind, C., Jacob, A., Evanno, G., Nusslé, S, \& Müller, R. (2008). Viability of brown trout embryos positively linked to melanin-based but negatively to carotenoid-based colours of their fathers. Proceedings: Biological Sciences, 275(1644), 1737-1744. doi: 10.1098/rspb.2008.0072

Westley, P. A., Stanley, R., \& Fleming, I. A. (2013). Experimental tests for heritable morphological color plasticity in non-native brown trout (Salmo trutta) populations. PLoS One, 8(11), e80401. doi: 10.1371/journal.pone.0080401

Williams, J. S., Hsu, J. Y., Rossi, C. C., \& Artinger, K. B. (2018). Requirement of zebrafish pcdh10a and pcdh10b in melanocyte precursor migration. Developmental Biology, 444(Suppl. 1), S274-S286. doi: 10.1016/j.ydbio.2018.03.022

Xu, P., Zhang, X., Wang, X., Li, J., Liu, G., Kuang, Y., ... Sun, X. (2014). Genome sequence and genetic diversity of the common carp, Cyprinus carpio. Nature Genetics, 46(11), 1212-1219. doi: 10.1038/ng.3098

Xu, X., Dong, G. X., Hu, X.S., Miao, L. Zhang, X. L., Zhang D. L., ... Luo, S. J. (2013). The genetic basis of white tigers. Current Biology, 23(11), 1031-1035. doi: 10.1016/j.cub.2013.04.054

Yamaguchi, Y., Brenner, M., \& Hearing, V. J. (2007). The regulation of skin pigmentation. Journal of Biological Chemistry, 282(38), 27557-27561. doi: 10.1074/jbc.R700026200

Yong, L., Peichel, C. L., \& McKinnon, J. S. (2015). Genetic architecture of conspicuous red ornaments in female threespine stickleback. G3, 6(3), 579-588. doi: 10.1534/g3.115.024505

Zastavniouk, C., Weir, L. K., \& Fraser, D. J. (2017). The evolutionary consequences of habitat fragmentation: body morphology and coloration differentiation among brook trout populations of varying size. Ecology and Evolution, 7(17), 6850-6862. doi: 10.1002/ece3.3229

Zhu, W., Wang, L., Dong, Z., Chen, X., Song, F., Liu, N., ... Fu, J. (2016). Comparative transcriptome analysis identifies candidate genes related to skin color differentiation in red tilapia. Scientific Reports, 6, 31347. doi: $10.1038 /$ srep31347 


\section{Captions of the Tables}

1278 Table 1: Uncorrelated pigmentation variables retained to build the forward selection model in

1279 RDA, and also used as a basis to multi-GWAS modelling. The full list of variables is reported

1280 in Table S1; correlation among variables in Table S2.

1281

1282 Table 2: List of the most indicative pigmentation- or colour-related genes associated to some

1283 CPLs ( $N=24 ; 30$ distinct loci) found in this study. The method of association that detected

1284 them is reported, together with their locations in the Atlantic salmon (Salmo salar) genome

1285 (Lien et al., 2016) and brown trout (S. trutta) high density linkage map of Leitwein et al.

1286 (2017). Their position in coding sequence or in a $25 \mathrm{~kb}$ window downstream or upstream the

1287 gene is reported. Significant GO-terms are reported. For each gene, relevant references with

1288 link to colour and/or skin features and pigmentation are provided. The full list of CPLs and 1289 other relevant information is given in Table S4. 


\section{Captions of the Figures}

1292 Fig. 1: RDA triplots for significant or nearly significant canonical axes 1 and 2, respectively.

1293 Pigmentation-related variables retained by forward modelling (Blanchet et al., 2008) are

1294 represented by arrows; description of the retained model in Table S4. Length of arrows is

1295 proportional to the strength of correlation of each variable with individual axis. Arrows

1296 pointing to different direction indicate negatively correlated variables (e.g. N.PR.Tot and the

1297 large pre-opercular black stain Macrost for RDA axis 1). The percentage of variance

1298 associated to each axis is reported, as well as the eigenvalue graph for constrained axis. (A):

1299 Individual trout are positioned on the map with positioning of SNPs as a grey block to the

1300 center of the factor map. Individuals have been coloured according to the nine clusters defined

1301 by Leitwein, Gagnaire, Desmarais, Berrebi, \& Guinand (2018) (top left); Clusters reflect the

1302 origin (hatchery $v s$ wild) of trout, but also the degree of admixture of each of them as

1303 measured by co-ancestry tracts. (B): Zoom on the centre of the map to illustrate the position

1304 of SNPs. SNPs departing \pm 2.5 standard deviates from the mean either on RDA axis 1 or RDA

1305 axis 2 have been coloured; a colour being associated to each pigmentation-related variable

1306 included in the model (insert). These SNPs are coloured with the variables they have been

1307 found the most significantly associated in the model. SNPs given as grey spots are within the

$1308 \pm 2.5$ S.D. interval and not considered in this study. Percentages of variation explained by

1309 each RDA axis are reported. Fish are representatives of hatchery Mediterranean (left) and

1310 Atlantic (right) individuals used in this study.

1312 Figure 2: Manhattan plots of multi-trait GWAS models selected using the MultiPhen package

1313 (O'Reilly et al., 2012), plus results associated to the single-trait GWAS model used in this 1314 study. The abscissa axis represents the forty brown trout LGs (Leitwein et al., 2017), the 
1315 ordinate axis reports values of $-\log _{10}(P)$, with $P$ being the probability of one association

1316 between a variable and a SNP (adjusted significance threshold based on permutation,

1317 Dudbridge \& Gusnanto, 2008). The red line indicates the $5 \times 10^{-8}$ significance threshold

1318 retained in this study. A: Results for the multi-trait GWAS for the model using two variables:

1319 N. PN.Tot and N.PR.Tot. The seven SNPs found significant in this model are represented by

1320 circles. The results from single trait GWAS have been added to this panel to provide a full

1321 summary of results. In this case, approximate position of the RAD-loci associated to the $N$.

1322 PN.Tot (17 loci) and N.PR.Tot (9 loci) variables are indicated by black and red arrows,

1323 respectively. One asterisk indicates two loci to close of each other to be indicated by separate

1324 arrows. The locus associated to the GJD2 gene on LG9 and also detected by the RDA is

1325 indicated by a longer arrow. B: Multi-trait GWAS based on the variables retained with the

1326 RDA except Zeb (31 candidate SNPs). The significance with each variable of the model is

1327 indicated by a different symbol. Each vertical line of symbols points to a single SNP. Some

1328 overlapping is possible. The full list of candidate SNPs detected using single and multi-trait

1329 GWAS are reported in Table S4. Variables labelled as in Table 1.

1330

1331 Figure 3: Distribution of $F_{S T}$ values for the 40,519 RAD-loci (blue) and for CPLs found

1332 significantly associated with RDA axis $1(N=320$ loci, reported in red in the insert). For each

1333 data set, mean $F_{S T}$ values and confidence intervals are provided as full and hatched lines,

1334 respectively. Mean values for the single- and multi-trait GWAS approaches are illustrated by

1335 the green and the orange lines, respectively. No confidence intervals are reported for GWAS

1336 because of the low number of CPLs detected with these approaches. Details in the main text.

1337

1338 Figure 4: Positioning of the 300 mapped CPLs detected in this study on the forty LGs of the 1339 brown trout. Loci found associated at least one single phenotypic trait are indicted by green, 

available under aCC-BY-NC 4.0 International license.

1340 red and yellow circles when detected with the RDA, single- or multi-GWAS analyses,

1341 respectively. Horizontal bars indicate the distribution of the full set of SNPs over LGs. The

1342 number of CPLs detected on each LG is indicated. As numerous loci are close to each other,

1343 circles may overlap. 


\section{Table 1}

1345

\begin{tabular}{|c|c|c|}
\hline Phenotypic variables & Description & Nature* (coding) \\
\hline N. PR. Tot & Total number of red spots over flanks & Q \\
\hline N. PN. Tot. & Total number of black spots over flanks & Q \\
\hline Diam. PN & Mean diameter of black spots & Q \\
\hline Oc. $P N$ & White ring around black spots & $\begin{array}{c}\text { SQ }(1=\text { no ring; } 2=\text { attenuated } / \text { thin } \\
\text { ring, } 3=\text { marked } / \text { thick ring })\end{array}$ \\
\hline Fr. D & Fringe on the dorsal fin & $\begin{array}{c}\mathrm{SQ}(1=\text { no fringe; } 2 \text { = white fringe } \\
3=\text { black \& white fringe })\end{array}$ \\
\hline Fr. An & Fringe on the anal fin & $\begin{array}{c}\mathrm{SQ}(1=\text { no fringe; } 2 \text { = white fringe, } \\
3=\text { black \& white fringe })\end{array}$ \\
\hline Fr. $P$ & Fringe on the pelvic fins & $\begin{array}{c}\text { SQ }(1=\text { no fringe; } 2=\text { white fringe } \\
3=\text { black } \& \text { white fringe })\end{array}$ \\
\hline L. Lat & Visibility of the lateral line & $\begin{array}{l}\text { SQ }(1=\text { not visible; } 2=\text { partially } \\
\text { visible; } 3=\text { fully visible) }\end{array}$ \\
\hline Parr & Presence of parr marks & SQ (1 = absence; 2 = presence $)$ \\
\hline Macrost. & $\begin{array}{l}\text { Macrostigma spot (large black dot on the } \\
\text { pre-opercular bone) }\end{array}$ & $\begin{array}{l}\text { SQ ( } 1=\text { absence; } 2 \text { = partially } \\
\text { visible/diluted; } 3=\text { fully visible) }\end{array}$ \\
\hline Zeb & Zebras on flank & SQ (1 = absence; 2 = presence) \\
\hline
\end{tabular}


bioRxiv preprint doi: https://doi.org/10.1101/2020.07.23.217109; this version posted August 17, 2020. The copyright holder for this preprint (which was not certified by peer review) is the author/funder, who has granted bioRxiv a license to display the preprint in perpetuity. It is made available under aCC-BY-NC 4.0 International license.

Admixture and pigmentation in the brown trout

\section{Table 2}

1349

\begin{tabular}{|c|c|c|c|c|c|c|c|c|c|c|}
\hline Shethod of A Asociation & LG - S m muma & LG. 5 s seler & 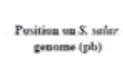 & 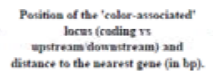 & 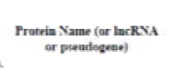 & Gene id & GO termin - Molecrular Functinas & GO terma - Riological procentes & Anoriated reference(t) & Notete \\
\hline $\mathrm{kDa}$ & 1 & 20 & 1665 sent & Deanurem 19ez ap & 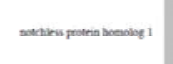 & sLET & & & 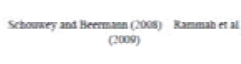 & 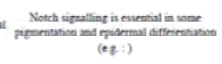 \\
\hline Seppecuwas,y protor & 1 & 29 & 3106510 & $\operatorname{cosente}$ & 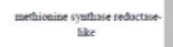 & MTRR & 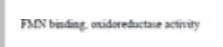 & 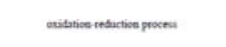 & been en at (cons) & 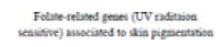 \\
\hline Matowowas? & 1 & $s$ & 39025500 & $\operatorname{cosens}$ & serib-Gituse & NTNG & & & 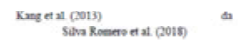 & cost cosix vaition \\
\hline Mumbewas 2 & 4 & 20 & 17851935 & Deenuream zan ip & 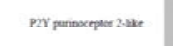 & nENZ & 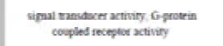 & 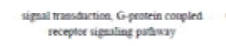 & 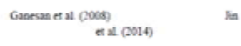 & Inpart metimopenew \\
\hline Mancwas & - & 12 & 1518674 & Downtrem 1234 to & Hescriptie factor $50 \mathrm{x}-10$ & soves & DNA vinang & 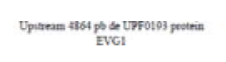 & 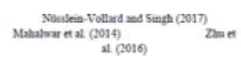 & 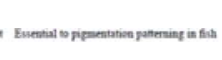 \\
\hline Susk_GWAS_NPS Tot & , & 1 & 1700028 & 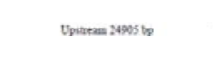 & 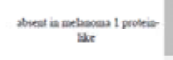 & stcase & & & 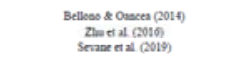 & 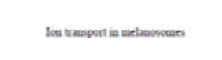 \\
\hline & , & ' & 1713244s & cosent & & sectses & & & & \\
\hline $\mathrm{RDA}$ & , & 1 & 2082072 & Upincen 12812 & 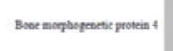 & BMP & 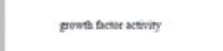 & 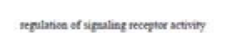 & 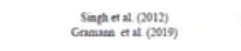 & 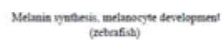 \\
\hline 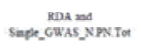 & , & 1 & 30055564 & Uptarem 213490 bs & 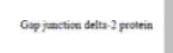 & GDD & & 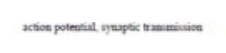 & 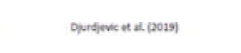 & 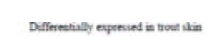 \\
\hline$R D A$ & 10 & 13 & 99645518 & 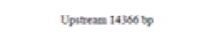 & semplastiota & SEMAD & & & Soceas ex $x$ (conis) & 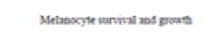 \\
\hline $\mathrm{RDA}$ & "1 & $s$ & 33615044 & cosant & nax faper pouten DC 4 & wa & 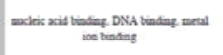 & 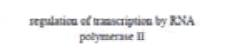 & 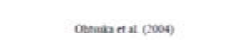 & 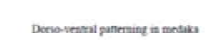 \\
\hline $\mathrm{RDA}$ & u & s & Al+asto & cosing & 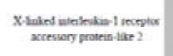 & MIRTL & & spal ramidatice & fine at (2006) & 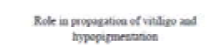 \\
\hline $\mathrm{RDA}$ & 16 & : & 14.5149m & Wontuce 2209 is & 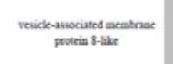 & van & & 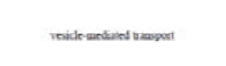 & Wide esal (WWor) & 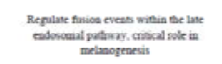 \\
\hline MouscowAS_2 2 & 17 & is & 7305903 & cosang & 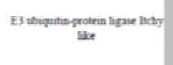 & $\mathrm{HCH}$ & 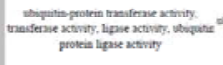 & 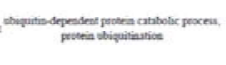 & 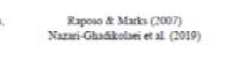 & 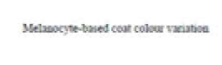 \\
\hline 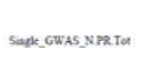 & 17 & is & 57874832 & Upterase 1038 op & 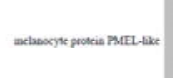 & PMIL & & & 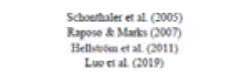 & 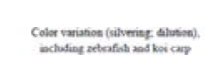 \\
\hline $\mathrm{RDA}$ & $n$ & 4 & 34306sso & $\operatorname{cosent}$ & 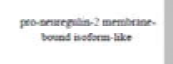 & $\mathrm{Naz}$ & & & 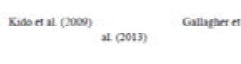 & 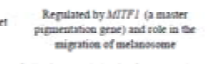 \\
\hline $\operatorname{Ros}$ & ${ }^{24}$ & $2 \pi$ & 5860133 & Desmiterem 11151 top & megin mas $v$ & IrGS & & 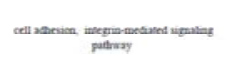 & 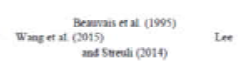 & 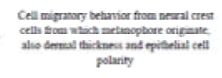 \\
\hline Manowas 7 & 24 & at & 5387363 & $\operatorname{cosent}$ & & mav & & & & \\
\hline $\mathrm{RDA}$ & 26 & $n$ & 44336701 & Descuirean 4503 bo & plecis-81-4se & REXII & 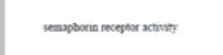 & 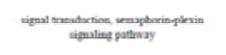 & 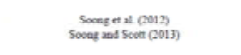 & 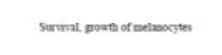 \\
\hline $\mathrm{RDA}$ & $n$ & , & 59001926 & Cpatem $237 \mathrm{sp}$ & 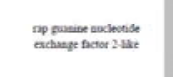 & RAPGEF & 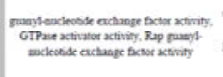 & 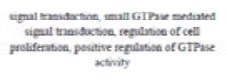 & Arenes al $(2000)$ & Repdative of melibopentis \\
\hline RDA & $n$ & , & 59002142 & Upteses 72010 & & RAPGEF & & & & \\
\hline RDA & n & , & 5785467 & cotant & 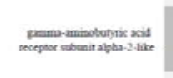 & GHBRA2 & 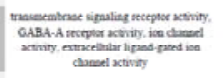 & 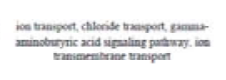 & Betroinver at 0016 . & 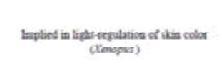 \\
\hline $\mathrm{RDA}$ & n & , & sassase & cosent & & GasRet2 & & & & \\
\hline$R D A$ & 3 & , & ร319392 & Dvesiurram 6546ty & 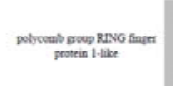 & PCGH & Dreat ina titsing & 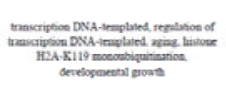 & 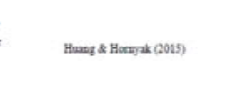 & 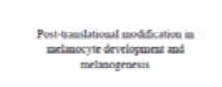 \\
\hline $\mathrm{RDA}$ & 31 & 9 & stsostat & Upertese $11700 \mathrm{op}$ & Froncaberin-10 & ACDHIO & eaveram ion tedang & 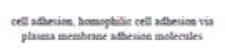 & whasum e at (2018) & 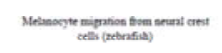 \\
\hline $\mathrm{RDA}$ & $n$ & , & G15184 & Downitrem 9983 top & & PCDHU & & & & \\
\hline $\mathrm{RDA}$ & 3 & , & 6151990 & Desnitem 1019s isp & protoca - Denib-10 & PCOHIS & . & . & . & . \\
\hline $\mathrm{RDA}$ & 31 & s & 0.2003472 & Desnurem 13ss top & 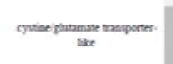 & secrail & 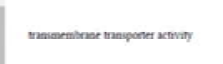 & 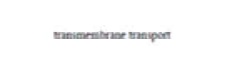 & 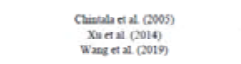 & 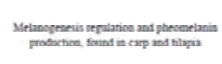 \\
\hline RDA & $n$ & , & t65991417 & cosing & proscadentio alphe C2tike & PCDHAC & calkiam ion tindang & 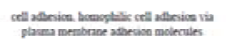 & Djateric enal colis) & Defferentialy equessed in mout shin \\
\hline$R D A$ & 31 & 9 & 7assoms & $\cos \sin x$ & 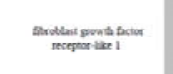 & PGRET & 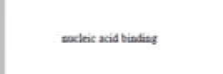 & DSA integratios & 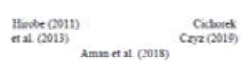 & 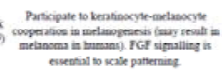 \\
\hline
\end{tabular}


bioRxiv preprint doi: https://doi.org/10.1101/2020.07.23.217109; this version posted August 17, 2020. The copyright holder for this preprint (which was not certified by peer review) is the author/funder, who has granted bioRxiv a license to display the preprint in perpetuity. It is made available under aCC-BY-NC 4.0 International license.

Admixture and pigmentation in the brown trout

\section{Figure 1:}

1353

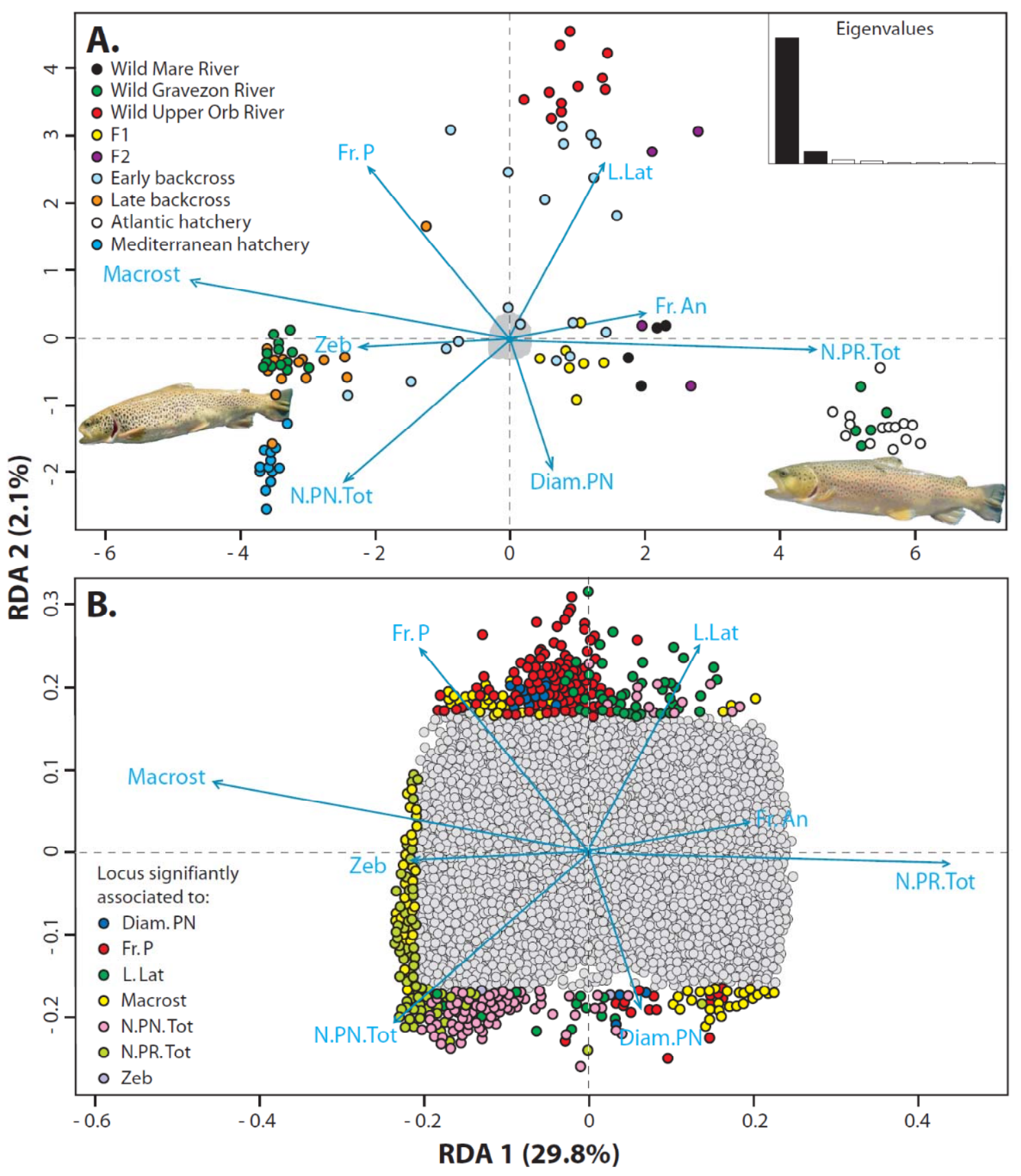

1355

1356 
bioRxiv preprint doi: https://doi.org/10.1101/2020.07.23.217109; this version posted August 17, 2020. The copyright holder for this preprint (which was not certified by peer review) is the author/funder, who has granted bioRxiv a license to display the preprint in perpetuity. It is made available under aCC-BY-NC 4.0 International license.

Admixture and pigmentation in the brown trout

\section{Figure 2:}
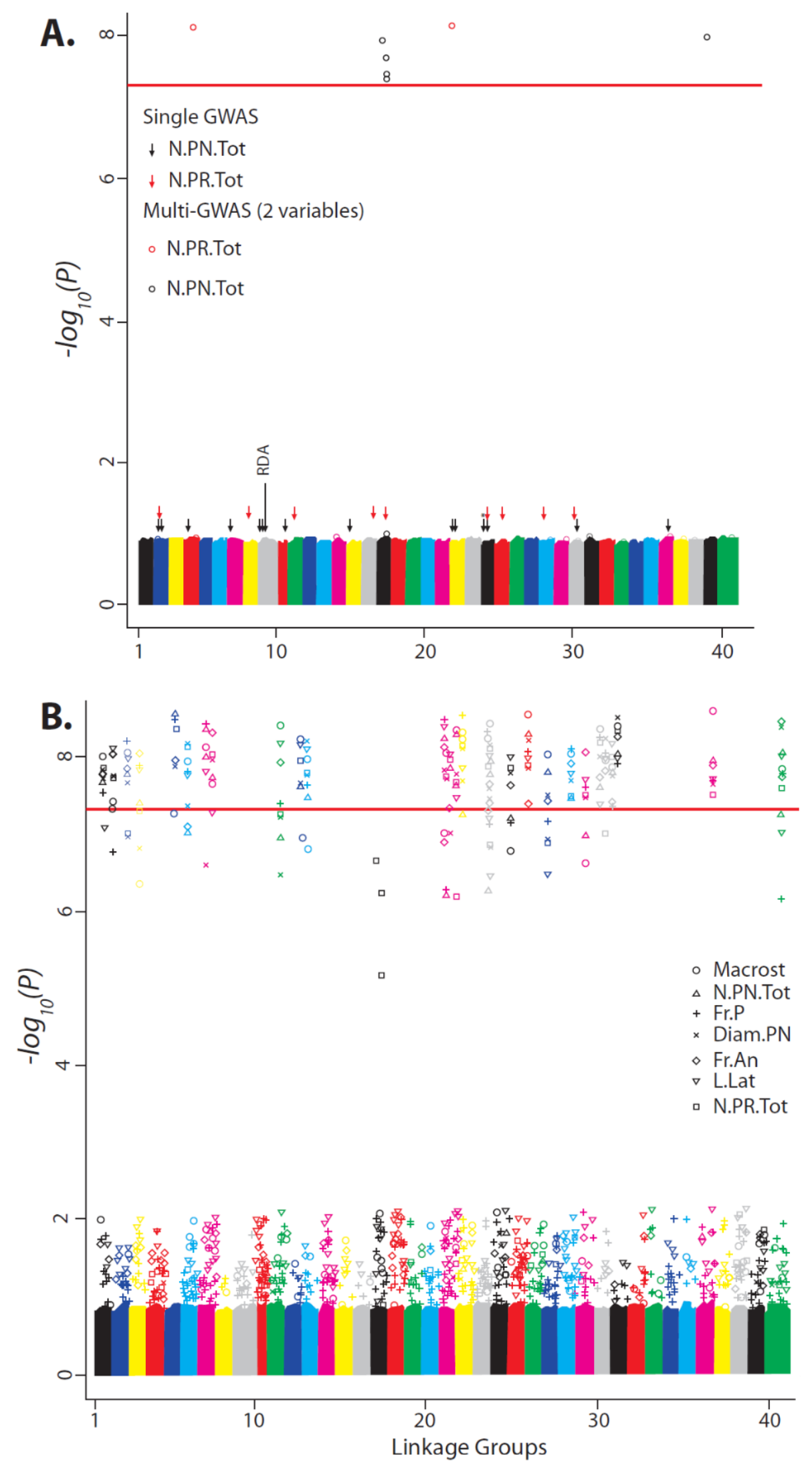
bioRxiv preprint doi: https://doi.org/10.1101/2020.07.23.217109; this version posted August 17, 2020. The copyright holder for this preprint (which was not certified by peer review) is the author/funder, who has granted bioRxiv a license to display the preprint in perpetuity. It is made available under aCC-BY-NC 4.0 International license.

\section{Figure 3:}

1360

1361

1362

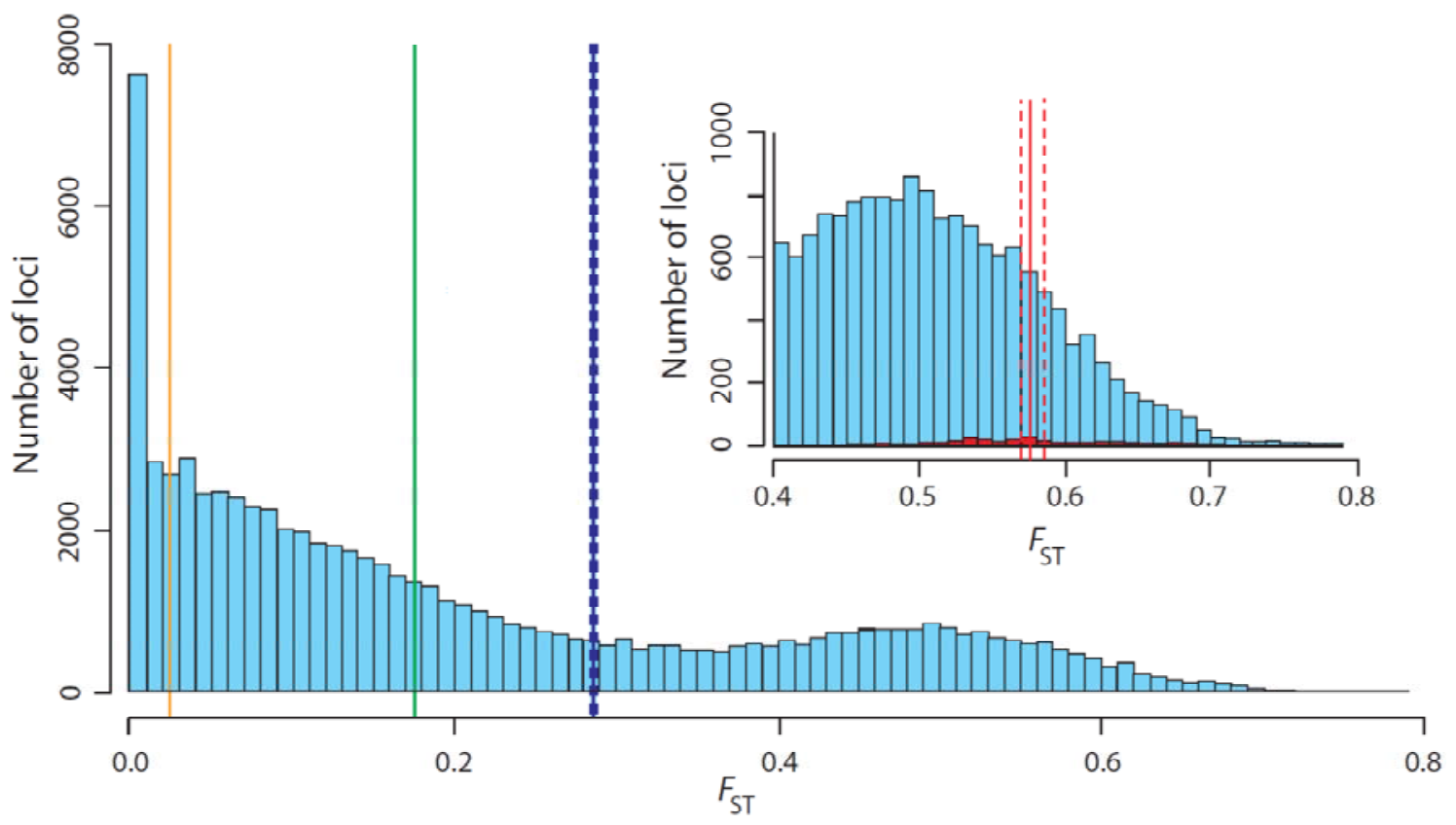

1363 
bioRxiv preprint doi: https://doi.org/10.1101/2020.07.23.217109; this version posted August 17, 2020. The copyright holder for this preprint (which was not certified by peer review) is the author/funder, who has granted bioRxiv a license to display the preprint in perpetuity. It is made available under aCC-BY-NC 4.0 International license.

Admixture and pigmentation in the brown trout

\section{Figure 4:}

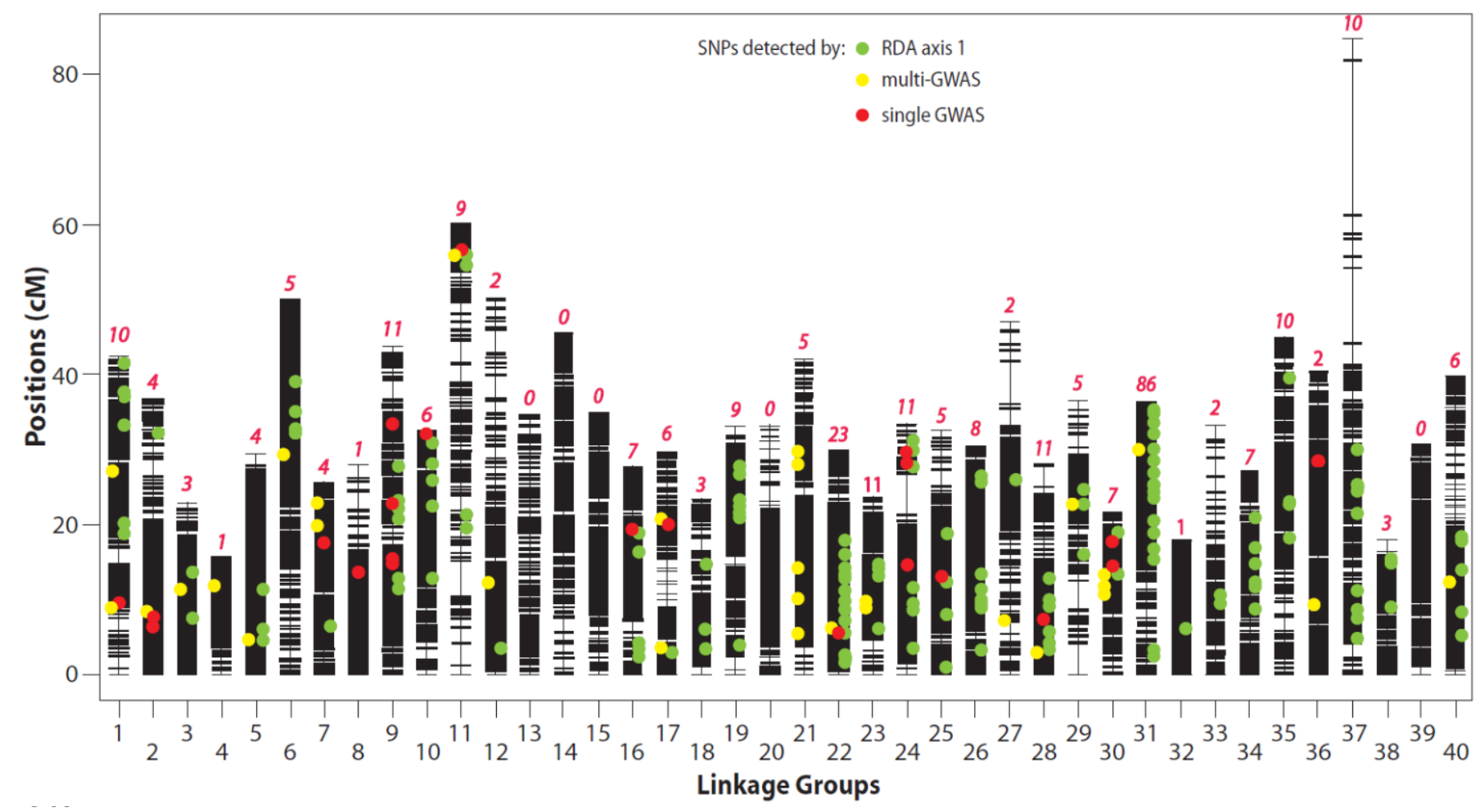

1366

1367 